Review

\title{
Applications of Supercritical Fluid Extraction (SFE) of Palm Oil and Oil from Natural Sources
}

\author{
Mohammed Jahurul Haque Akanda ${ }^{\mathbf{1}}$, Mohammed Zaidul Islam Sarker ${ }^{\mathbf{2}}$, Sahena Ferdosh ${ }^{1}$, \\ Mohd Yazid Abdul Manap ${ }^{3}$, Nik Norulaini Nik Ab Rahman ${ }^{4, *}$ and Mohd Omar Ab Kadir ${ }^{1, *}$
}

1 School of Industrial Technology, University Sains Malaysia, Minden, Penang 11800, Malaysia; E-Mails: jahurulhaque@yahoo.com (M.J.H.A.); sahenaferdosh@gmail.com (S.F.)

2 Department of Pharmaceutical Technology, Kulliyyah of Pharmacy, International Islamic University, Kuantan Campus, Kuantan, Pahang D/M 25200, Malaysia; E-Mail: zaidul@iium.edu.my Department of Food Technology, Faculty of Food Science and Technology, University Putra Malaysia, UPM Serdang, Selangor 43400, Malaysia; E-Mail: myazid@food.upm.edu.my

4 School of Distance Education, University Sains Malaysia, Minden, Penang 11800, Malaysia

* Authors to whom correspondence should be addressed; E-Mails: norulain@usm.my (N.N.N.A.R.); akmomar@usm.my (M.O.A.K.); Tel.: +6-046-585-435 (N.N.N.A.R.); Fax: +6-046-585-435 (N.N.N.A.R.); Tel.: +6-046-533-888 (M.O.A.K.); Fax: +6-046-573-678 (M.O.A.K.).

Received: 24 December 2011; in revised form: 8 February 2012 / Accepted: 9 February 2012 / Published: 10 February 2012

\begin{abstract}
Supercritical fluid extraction (SFE), which has received much interest in its use and further development for industrial applications, is a method that offers some advantages over conventional methods, especially for the palm oil industry. SC- $\mathrm{CO}_{2}$ refers to supercritical fluid extraction (SFE) that uses carbon dioxide $\left(\mathrm{CO}_{2}\right)$ as a solvent which is a nontoxic, inexpensive, nonflammable, and nonpolluting supercritical fluid solvent for the extraction of natural products. Almost $100 \%$ oil can be extracted and it is regarded as safe, with organic solvent-free extracts having superior organoleptic profiles. The palm oil industry is one of the major industries in Malaysia that provides a major contribution to the national income. Malaysia is the second largest palm oil and palm kernel oil producer in the World. This paper reviews advances in applications of supercritical carbon dioxide (SC-CO $\mathrm{CO}_{2}$ ) extraction of oils from natural sources, in particular palm oil, minor constituents in palm oil, producing fractionated, refined, bleached, and deodorized palm oil, palm kernel oil and purified fatty acid fractions commendable for downstream uses as in toiletries and confectionaries.
\end{abstract}


Keywords: supercritical fluid extraction; palm oil; palm kernel oil; major and minor constitutes of palm oil; use of palm oil; palm oil industry; bioactive lipid components

\section{Introduction}

The supercritical fluid extraction (SFE) technology has advanced tremendously since its inception and is a method of choice in many food processing industries. Over the last two decades, SFE has been well received as a clean and environmentally friendly "green" processing technique and in some cases, an alternative to organic solvent-based extraction of natural products. The most recent advances of SFE applications in food science, natural products, by-product recovery, pharmaceutical and environmental sciences have been published in extensive reviews [1]. The authors of these papers also discussed comprehensively the applications of SFE to extract high value compounds from food and natural products, as well as heavy metals recovery, enantiomeric resolution or drug delivery systems and the development of new separation techniques, such as using supercritical fluids to separate components of the extract, resulting in augmented quality and purity [2]. This makes SFE a valuable technique in the extraction of natural products, including fats and oils. These advantages are being used to remove caffeine from coffee [3], and harmful components from nutraceutical products [4]. SFE extracts the oil or desired element from the subjected material in shorter time compared to the conventional methods. Supercritical fluid extracts are typically sterilized, contamination free and the valuable components remain in chemically natural state $[5,6]$. SFE technology has also been investigated for the degumming and bleaching of soybean oil [7], palm oil [8,9], purification of used frying oil [10]; fractionation of butter oil [11] and beef tallow [12].

Supercritical fluid solvents are of interest in chemical processes both for their involvement in chemical reactions as well as their solvent effects, that are influenced by pressure and temperature. Supercritical fluid (SCF) solvents such as $\mathrm{SC}-\mathrm{CO}_{2}$ are intermediates between liquid and gases and considered important in the separation processes based on the physicochemical characteristics including density, viscosity, diffusivity and dielectric constant which are easily manipulated by pressure and temperature. A fluid that exists at a state above the critical temperature $\left(\mathrm{T}_{\mathrm{c}}\right)$ and the critical pressure $\left(\mathrm{P}_{\mathrm{c}}\right)$ is in a supercritical condition and the uniqueness of a SCF is that its density is pressure dependent. The density can be attuned from liquid to vapor condition with continuity.

In a SCF extraction process, the most important regions in the pressure-temperature-composition space are those of (i) 2-phase, liquid-vapour (LV), solid-vapor (SV), or liquid-liquid (LL) equilibrium; (ii) 3-phase, liquid-liquid-vapor (LLV), solid-liquid-vapour (SLV), solid-solid-vapor (SSV) equilibria, and sometimes; (iii) 4-phase equilibria: solid-SCF mixtures. As an extractive solvent, SCF can break up a multi component mixture based on the different volatile capacities of each component. Supercritical fluid extraction facilitates the detachment of the extract from the supercritical fluid solvent by simple expansion. An added benefit is derived from the liquid like densities of the supercritical fluids with superior mass transfer distinctiveness that enables the easy release of solutes, compared to other liquid solvents. This uniqueness is owed to the high diffusion and very low surface 
tension of the supercritical fluid that enables easy infiltration into the permeable make-up of the solid matrix to reach the solute [13-15].

Since the early 1980 s, the use of SC-CO $\mathrm{CO}_{2}$ in the extraction of oil or lipid from various sources, both plants [16-18] and animals [19,20] has been studied extensively. In addition, the application of $\mathrm{SC}-\mathrm{CO}_{2}$ in the extraction of minor constituents from various plant sources has also been widely studied [21,22]. Recently, Pourmortazavi et al. [23] reported that carbon dioxide is used in more than $90 \%$ of all analytical supercritical fluid extractions. The low critical temperature of carbon dioxide $\left(31.1^{\circ} \mathrm{C}\right)$ makes it attractive for thermally labile food products. Other solvents including ethane and propane are also used as supercritical fluids for the extraction of natural compounds. These solvents have high solvating power enabling higher solubility of lipid components compared to $\mathrm{SC}-\mathrm{CO}_{2}$. The main demerits of ethane and propane are their flammability and high cost.

Organic solvents such as hexane are used widely in lipid extraction and fractionation operations that can achieve almost complete recovery of oil from a sample matrix. In many countries, health and safety regulations are getting stricter in addressing environmental problems created by the use of organic solvents and these issues are forcing the industries to search for alternative processing methods. The solvent is unsafe to handle and unacceptable as it is harmful to human health and the environment, restricting its use in the food, cosmetic and pharmaceutical industries [24]. Furthermore, the major drawback of the solvent extracted products is the high level of residues left in the final products that must be desolventized before consumption. Therefore, $\mathrm{SC}-\mathrm{CO}_{2}$ is seen as a more favorable alternative to organic solvents in the extraction of fats and oils, and meets the growing consumer demand for safe natural fats and oils of excellent quality [25].

Pressure, temperature, particle size and sample pre-treatment are most important factors in oils as well as high value bioactive desired compounds extraction from the natural sources using supercritical fluid, because of the influence they have on the quality of the extracts. Many researchers have reported in detail the influential extraction parameters such as pressure, temperature, sample particle size and pre-treatment in the literature [26-29]. Generally, the solubility of the solute in the supercritical fluid solvent depends on the choice of SFE operating pressure and temperature [30]. These extraction parameters are in fact, directly responsible for the extract composition and component functionalities [31]. The performance of SFE or the quality of extracts can also be influenced by other factors such as bed geometry, the number of extraction and separation vessels and the solvent flow rate [32]. The main aim of this review paper is to give a detailed and updated discussion and analysis on research that has been conducted on the use of SFE in the extraction of oils, with special reference to palm oil, palm kernel oil and other oils from natural sources.

\section{Advantages and Economy of SC-CO 2 as a Solvent}

The application of carbon dioxide as a supercritical fluid has been extensively studied over the past three decades, especially in food processing. Supercritical fluid (SCF) at its critical temperature and pressure shows unique properties different from those of either gasses or liquids under standard conditions. Carbon dioxide can easily penetrate through the solid matrix and dissolve the desired extract due to its dual gaseous and liquid-like properties. SFE exploits the ability of chemicals to function as outstanding solvents for certain desired components under a suitable set of pressure and 
temperature conditions. The final products obtained by supercritical carbon dioxide $\left(\mathrm{SC}-\mathrm{CO}_{2}\right)$ extraction retain their quality and the stability of thermally labile natural components is assured without changing the bioactivity of natural molecules. SFE has been shown as a technically feasible alternative to both extraction and refining processes, especially for natural oils and bioactive compounds [33]. It is fairly rapid because of the low viscosity and high diffusivity associated with SCF. Extraction selectivity can be achieved by changing the temperature, pressure and co-solvent and the extracted material is easily recovered by simply depressurizing, allowing the supercritical $\mathrm{CO}_{2}$ to return to gaseous state and evaporate leaving little or no traces of solvent [34]. The natural fats and oils obtained by $\mathrm{SC}-\mathrm{CO}_{2}$ extraction are of excellent quality and are comparable to those obtained by organic solvent extraction methods [35]. The solvent power of $\mathrm{SC}-\mathrm{CO}_{2}$ is good since it dissolves non-polar to slightly polar compounds. The addition, of small quantities of polar organic solvent as modifiers can improve the extraction of polar compound by increasing the solubility of the analyte in $\mathrm{CO}_{2}$, or by reducing its interaction with the sample matrix or both [36]. Examples of the substances used thus far as supercritical solvents and their critical temperature and pressure are given in Table 1 [37].

Table 1. Examples of substances used as supercritical solvents and its corresponding critical temperature and pressure. Reproduced with substantial modification from [37].

\begin{tabular}{lcc}
\hline Gases & Critical Temperature (K) & Critical Pressure (MPa) \\
\hline Carbon dioxide & 304.17 & 7.38 \\
Ethane & 305.34 & 4.87 \\
Methane & 190.55 & 4.59 \\
Ethylene & 282.35 & 5.04 \\
Propane & 369.85 & 4.24 \\
Nitrous oxide & 309.15 & 7.28 \\
Acetylene & 308.70 & 6.24 \\
Hydrogen & 33.25 & 1.29 \\
Nitrogen & 126.24 & 3.39 \\
Oxygen & 154.58 & 5.04 \\
Neon & 44.40 & 2.65 \\
Argon & 150.66 & 4.86 \\
Xenon & 289.70 & 5.87 \\
\hline
\end{tabular}

Among them, $\mathrm{CO}_{2}$ is the most common supercritical fluid solvent, and has been extensively studied for its potential applications in many different fields, including the food processing industries. Due to the low critical temperature and pressure, low cost, wide availability, non-flammability and environmentally friendliness, supercritical $\mathrm{CO}_{2}$ is the most acceptable supercritical solvent in food applications as well as in other applications without any declaration [38]. As an example, cholesterol was shown to be more soluble in supercritical ethane than in $\mathrm{SC}-\mathrm{CO}_{2}$ [29]. As ethane is much more costly than $\mathrm{CO}_{2}$, the use of $\mathrm{CO}_{2}$ /ethane and $\mathrm{CO}_{2}$ /propane mixtures can be a good alternative for removal of cholesterol from food by compromising between higher ethane cost and better cholesterol removal efficiency, so supercritical fluid extraction can reduce the extraction and separation costs. Carbon dioxide can be recycled or reused from large scale SFE processes and is environmentally 
safe [39]. The $\mathrm{CO}_{2}$ used is largely a byproduct of industrial processes or brewing, and its use as supercritical solvent does not cause any extra emissions and cost.

\section{Palm Oil and Palm Kernel Oil Production}

Palm oil, also called palm fruit oil, is a natural edible vegetable oil obtained from the fruit of the palm tree. Based on the Hamburg-based Oil World Trade journal report, the global fats and oil production were 160 million tons in 2008. Palm oil and palm kernel oil contributed about 48 million tons or $30 \%$ of the total, while soybean oil was 37 million tons or $23 \%$. The palm oil has surpassed soybean oil as the most widely produced vegetable oil in the World. Palm is quite unique in that it yields two types of oil: palm oil from the mesocarp and palm kernel oil from the palm kernels. Palm kernels from where palm kernel oils (PKO) are obtained are, in fact, a by-product obtained from the processing of the palm fruits and its production has also been increasing. World production of palm kernel oil was 3,236 metric tons in 2003, of which Malaysia produced 1,644 metric tons [40]. The largest portion $(90 \%)$ of palm oil and its products are used for consumption, while the remaining $10 \%$ is utilized for nonedible purposes [41].

Malaysia is the second largest palm oil producer around the world, and produced 17.7 million tons of palm oil in 2008. Malaysia exports about $60 \%$ of palm oil around the World and this makes a significant contribution to its national economy [40]. Moreover, Malaysian palm oil is currently fulfilling most of the increasing global demands for oils and fats. This puts Malaysia in a favorable position to become a major supplier of raw materials for oleochemical industries both locally and overseas. Oleochemicals that are widely used in lubricants, plastics, resins, soaps, surfactants, emulsifiers, cosmetics, toiletries and other chemicals for the textile industries are produced from palm oil and its by-products. It is predicted that by 2012 palm oil will be the leading internationally traded edible oil. Palm oil is also cheaper than peanut oil, corn oil or soybean oil [42].

\section{Major Constituents of Palm Oil and Palm Kernel Oil}

Like all naturally occurring edible oils, palm oil and palm kernel oil are constituted mainly by triglycerides (TGs). More than $95 \%$ of palm oil consists of mixtures of TGs, formed from one molecule of glycerol with three fatty acids. Palm oil and palm kernel oil are high in saturated fatty acids, about $50 \%$ and $80 \%$, respectively. The ratio of unsaturated and saturated fatty acids in palm oil is well balanced. It contains $40 \%$ monounsaturated fatty acid (oleic acid), $10 \%$ polyunsaturated fatty acid (linoleic acid), 45\% palmitic acid and 5\% stearic acid (saturated fatty acids) [43]. The metabolites due to the biosynthesis of triglycerides (TGs) and products from the lipolytic activity such as monoglycerides (MGs), diglycerides (DGs) and free fatty acids (FFAs) form part of the palm oil components [44]. TGs are mainly responsible for the physical characteristics of palm oil such as melting point, solid fat content and the induction time of crystallization [45]. Palm oil and palm kernel oil differ in their physical and chemical characteristics, although they come from the same fruit [45]. The major fatty acids content in palm oil are palmitic and oleic acids, while palm kernel oil contains mainly 46.0 to $51.0 \%$ lauric acid and is generally termed as lauric oil [46].

Palm kernel oil contains some nonglyceride components. These components are removed or reduced to acceptable levels in order to convert it to edible form. The nonglycerides are of two broad 
types: oil-soluble and oil-insoluble. The oil soluble nonglycerides such as free fatty acids, trace metals, phospholipids, carotenoids, tocopherols/tocotrienols, oxidation products and sterols are more difficult to remove from the oil, and require various refining steps [47].

\section{Minor Constituents of Palm Oil/Palm Kernel Oil}

Palm oil comprises of two categories of minor constituents. The first category of constituents is made up of derivatives of fatty acid including acylglycerides, mainly monoglycerides and diglycerides, phosphatides, esters, and sterols. The second category comprises of non fatty acid related compounds, specifically hydrocarbons, and these include aliphatic alcohols, free sterols, tocopherols and pigments. Crude palm oil serves as one of the richest sources of biologically active carotenoids and the largest natural source of tocotrienol, which is a part of the vitamin E family.

Since 1980s the presence of carotenes and vitamin E in palm oil has been well acknowledged [48]. These minor constituents of palm oil have drawn attention worldwide due to their industrial applications and beneficial health effects. Compared to other plants palm oil is the richest source of carotenoids and vitamin E content, ranging from 500 to $3,000 \mathrm{mg} / \mathrm{kg}$ each, depending on the species of palm fruit $[49,50]$. On the other hand, palm-pressed fiber oil contains high level squalene, phytosterols, carotenes and vitamin E, ranging from 1,102 to 4,638 mg/ $\mathrm{kg}$ each, depending on whether fresh or dried fiber is used [51].

There are different types of carotenoids present in plants, bacteria, fungi and some animals. The various types of carotenes found in palm oil and fiber oil are summarized in Table $2[52,53]$.

Table 2. Composition (\%) of carotenes in palm oil and palm fiber oil $[52,53]$.

\begin{tabular}{lcc}
\hline Types of carotenes & Palm oil & Fiber oil \\
\hline Phytoene & 1.27 & 11.87 \\
Cis- $\beta$-Carotene & 0.68 & \\
Phytofluene & 0.06 & 0.40 \\
$\beta$-Carotene & 56.02 & 30.95 \\
$\alpha$-Carotene & 35.16 & 19.45 \\
Cis- $\alpha$-Carotene & 2.49 & 1.17 \\
S-Carotene & 0.69 & 7.56 \\
$\gamma$-Carotene & 0.33 & 2.70 \\
$\delta$-Carotene & 0.83 & 6.94 \\
Neurosporene & 0.29 & 3.38 \\
$\beta$-Zeacarotene & 0.74 & 0.37 \\
$\alpha$-Zeacarotene & 0.23 & Trace \\
Lycopene & 1.30 & 14.13 \\
\hline
\end{tabular}

Plant fruits are the major sources of carotenoids, which are antioxidants and widely used as natural colorants in the food processing industry [54]. Most recently, Machmudah et al. reported that carotenoids have been used as medicines for the treatment of cancer, cardiovascular disease and as immune system regulators [55]. Furthermore, carotenoids have been shown to be beneficial to human health, especially in the role of pro-vitamin A which is known to prevent xerophthlamia, a hardening of eye tissue related to night blindness. 
Among all other carotenoids, $\beta$-carotene is commonly and commercially used in food processing industry for its excellent coloring properties. $\beta$-carotene is a precursor of vitamin A and plays an important role in human health as well as the cellular regulatory system [56]. Apart from its colorant properties, $\beta$-carotene is known to have several other physiological functions, including antioxidant activity and inhibition of colon cancer cell growth [57]. It also has pharmaceutical, cosmetic and therapeutic uses [58]. Human beings cannot synthesis carotenoids in the body, so they need intake from food sources.

Lycopene is another important carotenoid. Lycopene $\left(\mathrm{C}_{40} \mathrm{H}_{56}\right)$ consists of a long chain hydrocarbon with conjugated 11 carbon-carbon double bonds. It is a natural red pigment and has extensive applications in the nutraceutical, pharmaceutical and in cosmetics market due to its natural deep-red pigments. Furthermore, it has potent antioxidant and anticarcinogen activity [59].

It is well known that palm oils as well as palm-pressed fiber oils are rich in vitamin E. Tocopherols and tocotrienols are the major vitamin $\mathrm{E}$ isomers found in crude palm oil as well as palm-pressed fiber oil. The average vitamin E concentration in fiber oil is $2,882 \mathrm{mg} / \mathrm{kg}$ [57]. Of all vitamin E isomers, tocotrienols constitute about $70-80 \%$ of total vitamin E present in crude palm oil [53]. However, in palm-pressed fiber oil, the major compound is $\alpha$-tocopherol, which is about $60-70 \%$ [46]. Natural tocopherols and tocotrienols are well absorbed by body tissue, therefore extraction of these components from natural sources is of interest [60]. Moreover, there is growing interest in tocopherols and tocotrienols in the food industries due to their antioxidant properties and other nutraceutical effects [61]. Tocopherol and tocotrienol have been shown to possess antitumor activity and also to reduce cardiovascular disease (CVD) [62]. In addition, tocopherols are used commercially to fortify food or as nutritional supplements. Most of the natural vitamin E is used for human consumption, while only a small portion is used for animal feed and cosmetics [63].

Phytosterols are used as intermediates for the synthesis of hormones and drugs and widely used as cholesterol-lowering agents in food and pharmaceuticals industries. Lau et al. [57] reported the highest concentration of sterols $10,877 \mathrm{mg} / \mathrm{kg}$ and squalene $9,690 \mathrm{mg} / \mathrm{kg}$ in palm oil. $\beta$-sitosterol is the major constituent at 70\% [51] and is potentially hypocholesterolemic [64]. Squalene acts as chemopreventive agent against some type of cancers $[65,66]$.

\section{Major Uses of Palm Oil and Palm Kernel Oil}

Palm oil and palm olein are used mainly as frying oils in the food industry around the World. They are widely used in large-scale industrial frying for the preparation of doughnuts, instant noodles, crisps, and chips and commercial frying of snack foods. Palm oil is an ideal oil due to its composition, natural consistency, appearance, pleasant smell and heat resistant nature. It is comparatively cheap to use and produce fried food products with good flavor and long shelf life. Palm oil contains only a moderate amount of the more stable linoleic acid (10-12\%). Palm olein is used both in the food industry and in homes and restaurants for frying and cooking. Palm olein produces less smoke, less foam and does not polymerize to gums compared to polyunsaturated oils. However, on repeated frying, a brown color is formed from the phenolic minor components in palm oil products but this color formation is unrelated to any deterioration of the fat. Because of the unique ratio of saturated to unsaturated TG, palm oil can be fractionated easily to a solid fat (stearin) and liquid oil (olein). These fractions can then be manipulated in different proportions to serve as raw materials for margarine 
production. Nowadays, margarines of different kinds are required to meet the varying demands by the food industries [67]. Hard margarine, soft table margarine and puff pastry margarine are some of the products made out of palm oil. There are many different kinds of palm-based shortenings, each tailor-made for a particular application.

PKO are widely used for the manufacture of margarine, cocoa butter substitutes and other confectionery fats, biscuits or cookies with filling creams, cake frostings, imitation whipping cream and many other fascinating food products [68]. It is also used as replacement of butterfat in various dairy products such as 'filled' milk (e.g., coffee 'whitener' and coffee 'creamer'), ice cream and cheese.

The Malaysian palm-based oleochemical industry has been advancing rapidly and is producing an increasing number of products like fatty acid methyl esters, fatty alcohols and glycerine [69]. In 2000, Malaysia produced 1.2 million tons of palm based oleochemicals, contributing to $19.7 \%$ of the total global production [70].

Figure 1. Flow diagram showing the usage of palm oil and palm kernel oil.

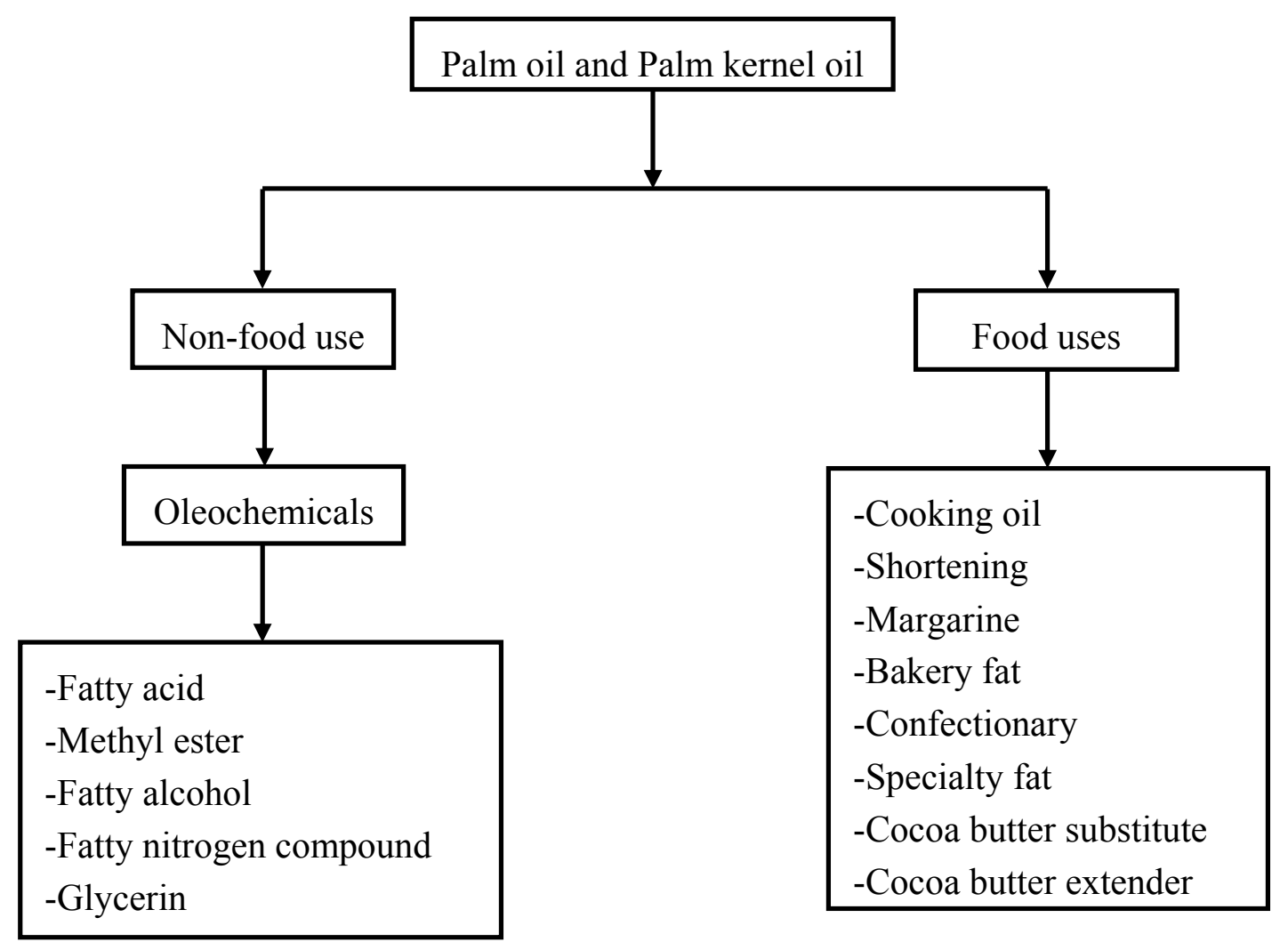

The fatty acid composition of palm kernel oil is very similar to that of coconut oil, while the fatty acid compositions of palm oil and palm stearin are similar to that of tallow [12]. Technically, therefore, palm kernel oil and palm oil could, to a large extent, replace coconut oil and tallow in the manufacture of oleochemicals provided availability and cost competitiveness are satisfactory. Oleochemicals are derived mainly from fatty acids and these can be manufactured from any of the oils and fats, but the ones actually used in the oleochemical industry are determined by market demand for particular types of fatty acids and their derivatives. All oils and fats can be converted to soap and the particular oil or fat used will determine the properties of the soap; and these properties of the soap are generally a function of the fatty acids. For the production of the best soaps no single oil or fat is suitable; a mixture 
of oils or fats has to be used. PKO closely resembles coconut oil and it is suitable in the production of high-quality soap. The major uses of palm oil and palm kernel oil are shown in Figure 1.

\section{Conventional Extraction of Palm Oil and Palm Kernel Oil}

In Malaysia, three methods are being used for extracting palm oil and palm kernel oil: screw press, direct solvent extraction, and pre-pressing followed by solvent extraction [46]. The screw press technology utilizes large quantities of water to sterilize the palm fruits as a pretreatment process. The process wastewater is then discharged as palm mill oil effluent (POME) and is harmful to the environment [71]. The solvent extraction processes can be divided into three main unit operations; kernel pre-treatment, oil extraction and solvent recovery from oil and meal. In this process the pre-treated kernel flakes are first pre-pressed, leaving about 15 to $20 \%$ oil in the pre-expelled cake. Finally the cake is solvent extracted to remove the remaining oil.

Physical and chemical treatments are two types of processes used to refine crude palm oil. Generally, physical refining is the more popular and advantageous method because it is the most economical means for removing undesirable substances and avoid concomitant environmental concerns. Typically, physical refining consists of three major steps. Degumming is the first step to remove undesired gummy materials such as phosphatides. Secondly, the bleaching step is involved to remove color pigments and the final step is deodorization process to get rid of the unpleasant odor and taste due to the presence of aldehydes and ketones. Deodorization of FFAs is by steam distillation at $270{ }^{\circ} \mathrm{C}$ under vacuum and the final product will be refined, bleached, and deodorized oil which requires three separate mills in addition to the logistics and cost in the processing. In other cases, organic solvents like hexane have been used to extract the oil. Moreover, some valuable nutrients such as tocopherols and carotenes present in palm oil are also destroyed during the removal of FFA via deodorization [8]. List et al. [7], reported that about $99.2 \%$ of the gums removed from crude soybean oil by $\mathrm{SC}-\mathrm{CO}_{2}$ degumming process while conventional water degumming removes $80-95 \%$. They also reported that after $\mathrm{SC}-\mathrm{CO}_{2}$ degumming crude soybean oil flavor stability is better than that of commercial refined oil. Manan et al. [9], described the modeling of a new SFE process for palm oil refining that can overcome the limitations of the existing refining processes. In comparing direct expelling, direct solvent extraction and pre-expelling/solvent extraction different opinions have been expressed regarding the most economical palm oil extraction method. Some feel direct solvent extraction is suitable for oilseeds containing less than $20 \%$ oil, while per-pressing followed by solvent extraction is used for high oil content seeds (exceeding 20\%).

\section{Applications of SFE in Palm Oil and Palm Kernel Oil Extraction}

\subsection{Supercritical Carbon Dioxide $\left(\mathrm{SC}-\mathrm{CO}_{2}\right)$ Extraction of Palm Kernel Oil}

Many researchers have investigated the extraction and fractionation of palm kernel oil from palm kernels using SFE [43,72-76]. The yield of PKO was shown to increase with pressure (34.5 to $48.3 \mathrm{MPa}$ at $353.2 \mathrm{~K}$ ). At lower pressure (20.7 to $27.6 \mathrm{MPa})$, lower amounts of shorter chain TGs (C8-C14) were obtained. More longer chain FA constituents (C16-C18:2) were extracted at higher pressures from 34.5 to $48.3 \mathrm{MPa}$. At higher temperature, the $\mathrm{SC}-\mathrm{CO}_{2}$ extracted $\mathrm{PKO}$ was found to be superior in terms 
of constituent fatty acids in TG compared to that obtained from Soxhlet extraction using hexane. Table 3 shows the TGs composition in PKO extracted by Soxhlet using hexane and by $\mathrm{SC}-\mathrm{CO}_{2}$ extraction at different temperature and pressure [43].

Table 3. Fatty acid constituents in palm kernel oil (PKO) extracted using Soxhlet and $\mathrm{SC}-\mathrm{CO}_{2}$ at different pressure and temperature $313.2 \mathrm{~K}$ and $353.2 \mathrm{~K}$. Reproduced with substantial modification from [43].

\begin{tabular}{|c|c|c|c|c|c|c|c|c|c|c|c|c|c|c|c|c|c|}
\hline \multicolumn{9}{|c|}{ Temperature (313.2 K) } & \multicolumn{9}{|c|}{ Temperature (353.2K) } \\
\hline \multirow{2}{*}{$\begin{array}{c}\text { Pressure } \\
\text { (MPa) }\end{array}$} & \multicolumn{8}{|c|}{ Fatty acids constituents $(\%)$} & Pressure & \multicolumn{8}{|c|}{ Fatty acids constituents (\%) } \\
\hline & $\mathrm{C}_{8}$ & $\mathrm{C}_{10}$ & $\mathrm{C}_{12}$ & $\mathrm{C}_{14}$ & $\mathrm{C}_{16}$ & $\mathrm{C}_{18: 0}$ & $\mathrm{C}_{18: 1}$ & $\mathrm{C}_{18: 2}$ & & $\mathrm{C}_{8}$ & $\mathbf{C}_{10}$ & $\mathbf{C}_{12}$ & $\mathrm{C}_{14}$ & $\mathrm{C}_{16}$ & $\mathrm{C}_{18: 0}$ & $\mathrm{C}_{18: 1}$ & $\mathrm{C}_{18: 2}$ \\
\hline 20.7 & 6.9 & 6.0 & 52.6 & 16.5 & 8.5 & 0.5 & 8.9 & 0.1 & 20.7 & 7.0 & 6.0 & 52.8 & 16.6 & 8.8 & 0.3 & 8.4 & 0.1 \\
\hline 27.6 & 6.2 & 5.4 & 52.1 & 16.0 & 8.1 & 0.9 & 10.5 & 0.8 & 27.6 & 6.4 & 5.6 & 52.9 & 16.3 & 7.3 & 0.8 & 10.1 & 0.7 \\
\hline 34.5 & 5.9 & 5.3 & 51.1 & 15.5 & 8.9 & 1.0 & 11.8 & 0.8 & 34.5 & 5.0 & 4.9 & 50.0 & 14.4 & 10.0 & 1.4 & 12.9 & 1.4 \\
\hline 41.4 & 5.3 & 5.0 & 51.6 & 14.6 & 9.8 & 1.1 & 11.9 & 0.9 & 41.4 & 4.1 & 4.0 & 48.0 & 12.7 & 11.9 & 2.1 & 14.5 & 2.8 \\
\hline 48.3 & 4.6 & 4.0 & 48.2 & 13.1 & 11.2 & 1.9 & 13.7 & 3.4 & 48.3 & 3.3 & 3.1 & 42.9 & 9.1 & 14.9 & 2.5 & 19.0 & 5.1 \\
\hline $\begin{array}{c}\text { Soxhlet } \\
\text { extraction }\end{array}$ & 4.0 & 3.7 & 48.0 & 15.4 & 7.5 & 2.0 & 15.1 & 2.7 & $\begin{array}{c}\text { Soxhlet } \\
\text { extraction }\end{array}$ & 4.0 & 3.7 & 48.0 & 15.4 & 7.5 & 2.0 & 15.1 & 2.7 \\
\hline
\end{tabular}

A pressurization-depressurization $\mathrm{SC}-\mathrm{CO}_{2}$ extraction technique (pressure swing technique) was used to separate PKO from undehulled ground palm kernel [38]. The PKO yields obtained by using combined pressure swing (PS) and continuous extraction are shown in Table 4. The authors compared these results with those of continuous $\mathrm{SC}-\mathrm{CO}_{2}$ extraction and combined PS extraction. Pressure swing extraction gave higher yield compared to continuous extraction at all pressures (Table 4). Moreover, they reported that the yield was doubled when PKO was extracted using a combined PS process for any given amount of $\mathrm{CO}_{2}$ used. They also claimed that, almost all of the oil from palm kernel particles extracted with combined pressure swing and continuous extraction with the use of a low amount of $\mathrm{CO}_{2}$. The highest total oil yield $46.9 \%$ was reported for the combined PS technique at $25 \mathrm{MPa}$ with $\mathrm{CO}_{2}$ flow rate of $2.49 \mathrm{~g} \mathrm{~min}^{-1}$. In comparison, the yield of the continuous extraction was lower $(34.9 \%)$ than the combined PS extraction at same pressure and carbon dioxide used.

Table 4. Yield of both combined pressure swing (PS) extraction and continuous extractions at various time intervals up to total extraction times of $150 \mathrm{~min}$. Reproduced with permission from Elsevier [38].

\begin{tabular}{cccccccccc}
\hline & \multirow{2}{*}{ Step } & Time & \multicolumn{8}{c}{ Yields (\%) } \\
\cline { 3 - 9 } & $(\mathbf{m i n})$ & \multicolumn{1}{c}{ Pressure swing extractions, pressure (MPa) } & \multicolumn{2}{c}{ Continuous extractions, pressure (MPa) } \\
\cline { 3 - 9 } & & $\mathbf{1 0}$ & $\mathbf{1 5}$ & $\mathbf{2 0}$ & $\mathbf{2 5}$ & $\mathbf{1 0}$ & $\mathbf{1 5}$ & $\mathbf{2 0}$ & $\mathbf{2 5}$ \\
\hline 1 & 10 & 1.6 & 2.8 & 4.5 & 9.9 & 0.8 & 1.2 & 2.4 & 3.9 \\
2 & 10 & 1.7 & 3.8 & 5.0 & 12.0 & 0.9 & 1.2 & 2.5 & 3.9 \\
3 & 10 & 1.7 & 2.7 & 3.3 & 4.6 & 1.0 & 1.4 & 2.4 & 4.1 \\
4 & 120 & 13.8 & 19.8 & 24.2 & 20.4 & 8.2 & 12.9 & 19.5 & 23.0 \\
Total & 150 & 18.8 & 29.1 & 37.0 & 46.9 & 10.9 & 16.7 & 26.8 & 34.9 \\
\hline
\end{tabular}

Note that step 4 consists of 120 min of continuous extraction for both PS extraction and continuous extraction. 
The color and fatty acid composition of the extracted PKO also varied with extraction pressure and temperature [76]. The variation in oil composition and thereby the characteristics such as slip melting point and solid fat content qualified each fraction to be used in different products, such as in margarine formulations and as a cocoa butter substitute. At a higher pressure and temperature of $48.3 \mathrm{MPa}$ and $80{ }^{\circ} \mathrm{C}$ respectively, the color and composition of the fractions did not change significantly, indicating low selectivity of $\mathrm{SC}-\mathrm{CO}_{2}$, whereas, the extraction rate and solubility of $\mathrm{PKO}$ in $\mathrm{SC}-\mathrm{CO}_{2}$ increased. Thus, a better and efficient extraction and fractionation process can be expected if the system is operated at higher pressures using multiple pressure reduction collectors [76].

Zaidul et al. [18] found some variations in the percent of fatty acids in different fractions of palm kernel oil. Shorter chain fatty acids (caprylic, capric, lauric and myristic acids) were found to decrease from the first to the last fraction but long chain fatty acids (palmitic, stearic, oleic and linoleic acids) increased from the first to the last fraction as the extraction period extended [18]. Thus, $\mathrm{SC}-\mathrm{CO}_{2}$ can obviously be applied in the selective reduction of short chain fatty acids in a particular fraction of extracted PKO. Similar results were reported for PKO and palm oil fractions by Markom et al. [77] and Norulaini et al. [75]. Norulaini et al. [74,75], studied further reduction of lauric acid and enhancement of oleic and stearic acids in PKO and was able to produce low-lauric or non-lauric confectionery fat.

\subsection{Supercritical Carbon Dioxide $\left(\mathrm{SC}-\mathrm{CO}_{2}\right)$ Extraction of Residual Palm Kernel Oil from Palm Kernel Cake to Produce Palm Kernel Fiber}

In palm oil mills, the residues remaining after the oil extraction is known as palm-pressed fiber and palm kernels. The application of SFE to palm-pressed fiber could be a novel process to recover the residual oil in the palm pressed fiber. The resulting defatted palm pressed fiber can be a good source of edible fiber for human consumption. Moreover, the residual palm kernel meal, a by-product obtained from the $\mathrm{SC}-\mathrm{CO}_{2}$ extraction process, is suitable for use as poultry feed owing to the reduced fiber content of the kernels [18].

The palm-pressed fiber is sterilized in order to inactivate bacteria and deactivate the lipases to prevent the enzymatic hydrolysis of lipids which releases FFAs [51]. Norulaini et al. [71], found that bacteria were completely removed when the fiber treatment were conducted at higher than the standard sterilization conditions. Several groups of researchers carried out the extraction of palm oil from palm press fiber [51,71]. The quality aspects, minor components and acylglycerols of fresh and dried palm-pressed fiber oil extracted using $\mathrm{SC}-\mathrm{CO}_{2}$ and hexane are given in Table 5 [51]. The quality of oil recovered from fresh palm-pressed fiber was generally better than the oil recovered from dried fiber. The concentrations of minor components in dried fiber oil were higher compared to fresh fiber oil for all extraction methods. The $\alpha$-tocopherol content was higher in dried fiber while $\gamma$-tocopherol was found to be higher in fresh fiber.

Palm-pressed fiber oil contains palmitic acid as the major FA, followed by oleic acid. Palmitic acid showed higher yield at lower pressure $(13.7 \mathrm{MPa})$, but oleic acid reflected higher yield at higher pressure (27.6 MPa). Linoleic acid required the highest pressure (34.5 MPa) as tested in Lau et al.'s study [51]. The variation in FA composition of $\mathrm{SC}-\mathrm{CO}_{2}$ extracts is due to variation in solubility of different fatty acids at variable extraction conditions. Higher pressure is needed to dissolve the longer 
chain FAs (C18:0, C18:1, C18:3, C20:0 and C20:1) relative to short and medium chain FAs $(\mathrm{C} 8, \mathrm{C} 10, \mathrm{C} 12$ and $\mathrm{C} 14)$.

Table 5. The physico-chemical characteristics, minor components and acylglycerol contents in the $\mathrm{SC}-\mathrm{CO}_{2}$ and hexane extracted palm fiber oil ${ }^{\mathrm{a}}$. Reproduced with substantial modification from [51].

\begin{tabular}{|c|c|c|c|c|c|c|}
\hline \multirow{2}{*}{$\begin{array}{l}\text { Sample } \\
\text { Extraction } \\
\text { method }\end{array}$} & \multicolumn{3}{|c|}{ Fresh fiber } & \multicolumn{3}{|c|}{ Dried fiber } \\
\hline & $\begin{array}{c}\mathrm{SC}-\mathrm{CO}_{2} \\
\left(50{ }^{\circ} \mathrm{C},\right. \\
30 \mathrm{MPa})\end{array}$ & $\begin{array}{c}\mathrm{SC}-\mathrm{CO}_{2} \\
\left(80{ }^{\circ} \mathrm{C}\right. \\
30 \mathrm{MPa})\end{array}$ & hexane & $\begin{array}{c}\mathrm{SC}-\mathrm{CO}_{2} \\
\left(50^{\circ} \mathrm{C},\right. \\
30 \mathrm{MPa})\end{array}$ & $\begin{array}{c}\mathrm{SC}-\mathrm{CO}_{2} \\
\left(80{ }^{\circ} \mathrm{C}\right. \\
30 \mathrm{MPa})\end{array}$ & hexane \\
\hline \multicolumn{7}{|l|}{$\begin{array}{l}\text { Physico-chemical } \\
\text { characteristics }\end{array}$} \\
\hline DOBI $(\%)$ & $2.21 \pm 0.12$ & $2.19 \pm 0.09$ & $2.01 \pm 0.08$ & $2.69 \pm 0.05$ & $2.58 \pm 0.10$ & $2.08 \pm 0.07$ \\
\hline OSI (h) & $21.9 \pm 0.15$ & $18.8 \pm 0.11$ & $>48$ & $16.6 \pm 0.32$ & $16.1 \pm 0.22$ & $33.7 \pm 0.34$ \\
\hline $\mathrm{PV}\left(\right.$ meq O$\left._{2} / \mathrm{kg}\right)$ & $0.46 \pm 0.03$ & $0.52 \pm 0.03$ & $0.84 \pm 0.04$ & $1.83 \pm 0.05$ & $2.34 \pm 0.06$ & $2.23 \pm 0.04$ \\
\hline FFA $(\%)$ & $3.46 \pm 0.05$ & $3.84 \pm 0.04$ & $3.94 \pm 0.03$ & $3.79 \pm 0.05$ & $3.78 \pm 0.06$ & $3.94 \pm 0.03$ \\
\hline \multicolumn{7}{|l|}{$\begin{array}{l}\text { Minor component } \\
(\mathrm{mg} / \mathrm{kg})\end{array}$} \\
\hline Carotenes & $2909 \pm 15$ & $3424 \pm 13$ & $2933 \pm 11$ & $4424 \pm 16$ & $4638 \pm 21$ & $4007 \pm 15$ \\
\hline Vitamin E & $1979 \pm 14$ & $2372 \pm 14$ & $1981 \pm 18$ & $2303 \pm 19$ & $2584 \pm 17$ & $2251 \pm 13$ \\
\hline Phytosterols & $4429 \pm 31$ & $4409 \pm 27$ & $4349 \pm 33$ & $4749 \pm 31$ & $4568 \pm 19$ & $4610 \pm 22$ \\
\hline Squalene & $1102 \pm 21$ & $1321 \pm 18$ & $1117 \pm 20$ & $1642 \pm 22$ & $1633 \pm 12$ & $1495 \pm 25$ \\
\hline \multicolumn{7}{|l|}{$\begin{array}{l}\text { Acylglycerol } \\
\text { content }(\%)\end{array}$} \\
\hline MAG & $0.35 \pm 0.02$ & $0.38 \pm 0.03$ & $0.37 \pm 0.04$ & $0.31 \pm 0.02$ & $0.28 \pm 0.03$ & $0.27 \pm 0.02$ \\
\hline DAG & $0.85 \pm 0.02$ & $0.89 \pm 0.05$ & $1.14 \pm 0.03$ & $0.86 \pm 0.04$ & $0.83 \pm 0.04$ & $0.92 \pm 0.02$ \\
\hline TAG & $94.30 \pm 1.03$ & $93.73 \pm 0.79$ & $93.52 \pm 1.12$ & $93.73 \pm 0.32$ & $93.78 \pm 0.77$ & $93.87 \pm 0.62$ \\
\hline
\end{tabular}

Each sample was analyzed in triplicates a. DOBI: Deterioration of bleachability index, OSI: Oxidative stability index, PV: Peroxide value, FFA: Free fatty acid, MAG: Monoacylglycerol, DAG: Diacylglycerols, TAG: Triacylglycerols.

\subsection{Supercritical Carbon Dioxide (SC-CO 2$)$ Fractionation of Palm Kernel Oil}

Selective extraction of low vapor pressure oils can be done using supercritical fluids which is not easily attainable by distillation. These oils cannot be fractionated by distilling because of the presence of impurities with equal volatility as the main components, thus failing to achieve good fractionation. Fractionation using supercritical fluid with respect to chemical composition to produce oil fractions with different carbon lengths and saturations has been investigated. Hassan et al. [76], fractionated PKO through supercritical carbon dioxide extraction. For the extraction and fractionation of PKO, the SC- $\mathrm{CO}_{2}$ was used as a solvent in the pressure range 20.7-48.3 $\mathrm{MPa}$ and temperatures between 40 and $80{ }^{\circ} \mathrm{C}$. At lower pressures 20.7 and 27.6 MPa, the solubility of PKO in SC-CO2 decreased with temperature while at higher pressures of $34.5,41.4$ and $48.3 \mathrm{MPa}$, the solubility increased with temperature. The authors found that the earlier fractions rich in short-chain triglicerides, while the later fractions were rich in longer chain triglicerides and unsaturated triglicerides. The authors also reported that the short chain fatty acid contained in $\mathrm{PKO}$ are easily soluble in $\mathrm{SC}-\mathrm{CO}_{2}$. 


\subsection{Supercritical Carbon Dioxide $\left(\mathrm{SC}-\mathrm{CO}_{2}\right)$ Palm Kernel Oil Fractions to Make Cocoa Butter Replacers (CBRs)}

Supercritical carbon dioxide is a convenient solvent for the fractionation of $\mathrm{PKO}$, reducing shorter and medium chain $\left(\mathrm{C}_{8}-\mathrm{C}_{14}\right)$, and increasing the longer chain $\left(\mathrm{C}_{18: 0}-\mathrm{C}_{18: 2}\right)$ fatty acid constituents in PKO [72,75]. Many researchers have fractionated fatty acid triglycerides based on carbon number using $\mathrm{SC}-\mathrm{CO}_{2}$ in the temperature range of $40-80{ }^{\circ} \mathrm{C}$ and pressures up to $50 \mathrm{MPa}[72,74-76,78,79]$. Zaidul et al. [68], studied the blending of fractionated $\mathrm{PKO}$ obtained by $\mathrm{SC}-\mathrm{CO}_{2}$ extraction and palm oil for the production of CBRs. In that study a total of 10 blends were studied. The authors have successfully produced CBRs in respect to the physio-chemical properties such as fatty acid constituent, slip melting point (SMP), iodine value (Iv), saponification value ( $\mathrm{Sv})$, acid value (Av), cloud point $(\mathrm{Cp})$ and solid fat content (SFC).

\subsection{Supercritical Carbon Dioxide (SC-CO $\mathrm{C}_{2}$ Extraction of Oil from Solid Matrix}

SCF or near SCF extractions of palm oil fruits using palm oil liquid can be conducted at elevated temperatures. The underlying principal behind this process is the phase equilibrium of palm oil and supercritical palm oil as solvents to extract oil from oil palm fruits at various temperatures and pressures. A study beyond the critical points can be conducted in the near future. In this novel extractions of the palm oil as the soluble constituent, the extract must first be released from its bound state, thereafter diffuse through the porous structure and finally through the fluid layer. At present there is a lack of knowledge about the phase equilibrium for this system, solubility, diffusivity and the mass transfer rate for the overall process. In general, such rates are controlled by the combination of internal and external diffusion resistances. In order to effectively emulate the extraction processes, the solubility of the palm oil as the solute in the supercritical palm oil which acts as the solvent is the most important thermo physical property that must be determined. In particular, the pressure and temperature, as well as the density dependence of solubility must be determined. This information is necessary before the operating conditions can be determined.

In the palm oil industry, the objectives that are of significance to decision makers are to maximize crude palm oil and palm kernel oil production and to minimize losses of palm oil and palm kernel during processing and also to bring production costs to the lowest possible level. SCF technology has a number of advantages over the conventional processing methods for the extraction, purification and fractionation of palm oil [8,72]. These include low-temperature operation, selective separation, inert solvent, little wastewater and the extraction of a high-value product or a new product with improved functional or nutritional properties. Considerable attention has been given to the development of SCF processing in the oil and fat industry. However, use of $\mathrm{SC}-\mathrm{CO}_{2}$ for the extraction of palm oil from its fruits has been found to be relatively rare as compared to $\mathrm{SC}-\mathrm{CO}_{2}$ extraction of other vegetable oils.

\subsection{Supercritical Carbon Dioxide (SC-CO $)$ Extraction of Oil from Mesocarp}

There are few available palm oil studies reporting on the extraction [80] and fractionation [77] of the oil from the fleshy mesocarp. Lau et al. found that the oil recovery from dried mesocarp was slightly higher (77.3\%) using SC- $\mathrm{CO}_{2}$ compared to mechanical screw-pressing (74.2\%) [80]. The free 
fatty acid content in $\mathrm{SC}-\mathrm{CO}_{2}$-extracted palm oil was low $(0.61 \%)$ when compared to conventionally extracted crude palm oil (3.15\%). The quality of commercial crude palm oil (CPO) was determined by the measurement of bleachability index (DOBI), oxidative stability index (OSI), peroxide value (PV) and free fatty acid (FFA) value [80]. The determination of the quality of commercial CPO and CPO extracted using SC- $\mathrm{CO}_{2}$ and hexane is shown in Table 6 [80].

Table 6. The physico-chemical characteristics, trace metals, minor components and acylglycerol contents in the $\mathrm{SC}-\mathrm{CO}_{2}$, hexane and commercial extracted palm oil. Reproduced with substantial modification from [80].

\begin{tabular}{lccc}
\hline & \multicolumn{3}{c}{ Extraction method } \\
\hline & $\mathrm{SC} \mathrm{CO}_{2}$ & Hexane & Commercial CPO \\
\hline Physico-chemical characteristics & & & \\
DOBI (\%) & 2.60 & $2.93 \pm 0.24$ & $2.75 \pm 0.31$ \\
Oxidative stability index (OSI) (h) & 14.79 & $16.08 \pm 1.03$ & $15.50 \pm 0.96$ \\
Peroxide value (PV) (meq $\left.\mathrm{O}_{2} / \mathrm{kg}\right)$ & 1.68 & $1.47 \pm 0.32$ & $1.94 \pm 0.27$ \\
Free fatty acid (FFA) (\%) & 0.612 & $0.371 \pm 0.093$ & $3.15 \pm 0.35$ \\
\hline Trace metal content (mg/kg) & & & \\
Iron & 0.51 & $6.26 \pm 1.02$ & $6.06 \pm 2.12$ \\
Copper & 0.05 & $0.22 \pm 0.05$ & $0.12 \pm 0.10$ \\
\hline Minor component (mg/kg) & & & \\
Carotenes & 972 & $906 \pm 64$ & $879 \pm 72$ \\
Vitamin E & 512 & $557 \pm 42$ & $614 \pm 34$ \\
Phytosterols & 826 & $768 \pm 38$ & $674 \pm 21$ \\
Squalene & 632 & $627 \pm 39$ & $524 \pm 22$ \\
\hline Acylglycerol content (\%) & & & \\
MAG & 0.14 & $0.15 \pm 0.03$ & $0.14 \pm 0.04$ \\
DAG & 4.16 & $4.32 \pm 1.17$ & $5.51 \pm 1.62$ \\
TAG & 94.95 & $94.81 \pm 2.53$ & $91.93 \pm 2.17$ \\
\hline
\end{tabular}

The OSI of $\mathrm{SC}-\mathrm{CO}_{2}$-extracted palm oil also was slightly lower than commercial and hexane-extracted crude palm oil because the pro-oxidants iron and copper (trace metals) were reduced in the $\mathrm{SC}-\mathrm{CO}_{2}$-extracted oil but the overall quality of $\mathrm{SC}-\mathrm{CO}_{2}$-extracted $\mathrm{CPO}$ appeared equivalent to that obtained by commercial processing of CPO (Table 6). In the palm oil industry, the extraction, fractionation and refining of commercial crude palm oil could be contaminated with iron and copper by the soil and wear and tear of the processing machinery [80]. On the other hand, the single processing operation of SFE is combined and very simplified for the extraction, fractionation and refining of palm oil, gives less opportunity to oil contamination or reduce the level of iron and copper in the oil. It can be concluded that the SFE technique may widely used in palm oil industries for trace metals-free good quality oil production. It was also found that triglycerides and minor components such as carotenes, phytosterols, and squalene in the $\mathrm{SC}-\mathrm{CO}_{2}$-extracted palm oil are higher compared to hexane-extracted and commercially extracted palm oil. So, the study showed that the palm oil extraction by using $\mathrm{SC}-\mathrm{CO}_{2}$ can potentially replace the conventional screw press extraction, clarification and vacuum drying processes [80]. 
SFE is able to fractionate, refine, and bleach. Deodorization from SFE extracted oil is done under steam after extraction. Using countercurrent SFE, the free fatty acid removal from crude oil can be done within a short period without any loss of triglyceride [81]. Manan et al. successfully designed a new process for the production of refined palm oil based on SFE technology by using the Aspen Plus simulator [9]. This simulator may be used for stead state or transient calculations. This process was also found to be suitable for enriching tocopherols and to remove the FFA from CPO using $\mathrm{SC}-\mathrm{CO}_{2}$ as solvent.

Besides extraction and refining, simultaneous fractionation of palm oil by supercritical fluid is also possible. During extraction the initial fraction is solid and the latter fractions are semi-liquid and liquid at room temperature [77]. The solid appearance of the initial fractions is due to the high content of saturated fatty acid (mainly $\mathrm{C} 16: 0$ ) rich triglycerides; they appear first due to their high solubility in $\mathrm{SC}-\mathrm{CO}_{2}$. The liquid fractions contain mostly triglycerides rich in unsaturated FAs (mainly $\mathrm{C} 18: 1$ ). The concentration of the short chain and saturated FAs in palm oil decreases as the extraction time increases. Conversely, the concentration of the heavier and mainly unsaturated FAs increases with the progress in extraction, after most of the shorter chain FAs have been removed making these longer chains accessible to the $\mathrm{SC}-\mathrm{CO}_{2}$.

\section{SFE of Minor Constituent of Palm Oil}

Minor components in palm oil such as carotenoids, vitamin E, sterols, squalene and others are mostly removed from the oil during traditional oil refining procedures [82]. Palm oil has been used to extract these natural valuable compounds by employing various methods. They include urea processing, saponification, separation by adsorption, crystallization, selective solvent extraction, molecular distillation and transesterification followed by molecular distillation $[49,83]$. However, the difficulty and inefficiency of most of these methods are ascribed to the sensitivity of carotene to light, oxygen, heat and acid degradation, low content in all natural sources, and low selectivity of separation techniques due to the similar physical properties (polarity, solubility, molecular weight) of the various carotenes [58]. Moreover, use of organic solvent in these methods which are potentially harmful and cost effective. SC- $\mathrm{CO}_{2}$ extraction has become an increasingly popular method for the valuable natural minor components of palm oil, due to its distinctive advantages, as well as low temperature use, selective extraction, simpler and cleaner (solvent-free) product recovery as well. The application of supercritical fluid extraction of carotenes and vitamin E from palm oil is seen to have great potential for replacing the conventional screw-press extraction, clarification and vacuum drying processes [51]. Several other reports are available on the $\mathrm{SC}-\mathrm{CO}_{2}$ extraction of carotenoids and vitamin $\mathrm{E}$ from palm and palm-pressed fibers oil $[8,71,84]$. Furthermore, The $\mathrm{SC}-\mathrm{CO}_{2}$ extraction of carotene and the impact of pressure, temperature and time have been extensively studied by many researchers [52,57,85-88].

Lau et al. [57], extracted two fractions of fiber oil enriched with vitamin $\mathrm{E}$ and carotene, respectively from fresh palm-pressed mesocarp fiber using $\mathrm{SC}-\mathrm{CO}_{2}$ at $40{ }^{\circ} \mathrm{C}$ in three steps by a continuous extraction technique. About $40 \%$ of the triglyceride with low carotene content was obtained at $10 \mathrm{MPa}$ and $20 \mathrm{MPa}$ in the earlier fraction, retaining maximum carotene that enriched the latter fractions with average concentration of $3,942 \mathrm{mg} / \mathrm{kg}$ and $90 \%$. The vitamin E was extracted with highest concentration of $3,650 \mathrm{mg} / \mathrm{kg}$ in the first fraction, while carotene was enriched to $5,498 \mathrm{mg} / \mathrm{kg}$ in the later fraction. From their study, it has been shown that the solubility of vitamin $\mathrm{E}$ in $\mathrm{SC}-\mathrm{CO}_{2}$ is 
higher than that of carotene. Therefore, carotenes can be separated from other minor components based on solubility differences by manipulating the $\mathrm{SC}-\mathrm{CO}_{2}$ extraction parameters.

To date, the solubility of carotenoids and vitamin $\mathrm{E}$ in supercritical carbon dioxide and the effect of pressure, temperature have been widely studied. Wei et al. [52], reported the effect of pressure, temperature, on the solubility of palm carotenoids. They found that the solubility of carotenoids in $\mathrm{SC}-\mathrm{CO}_{2}$ is affected by increasing pressure at the constant temperature or decreasing temperature at constant pressure. However, increasing flow rate and decreasing sample size can reduce extraction time. The solubility of carotenoids found in their study is in the range between $1.31 \times 10^{-4}$ to $1.58 \times 10^{-3} \mathrm{~g} \mathrm{~kg}^{-1}$ at different pressure range 14 to $30 \mathrm{MPa}$ while lower solubility was also reported by Johannsen and Brunner with $1 \times 10^{-3}$ to $4 \times 10^{-2} \mathrm{~g} \mathrm{~kg}^{-1}$ [88].

Tocopherol and carotene differ greatly in their solubility in $\mathrm{SC}-\mathrm{CO}_{2}$. The solubility of squalene and sterols in supercritical fluids was studied by Lau et al. [57]. In their study, the solubility of squalene in the mixture at $10 \mathrm{MPa}$ was $0.189 \mathrm{mg} / \mathrm{g} \mathrm{CO}_{2}$ while that of sterols was $0.132 \mathrm{mg} / \mathrm{g} \mathrm{CO}_{2}$, even though the initial concentration of sterols $(4,349 \mathrm{mg} / \mathrm{kg})$ was four times higher than that of squalene $(1,117 \mathrm{mg} / \mathrm{kg})$. Squalene showed high solubility in low density $\mathrm{SC}-\mathrm{CO}_{2}(10 \mathrm{MPa})$ with a $77 \%$ recovery during the 1 st $4 \mathrm{~h}$ of extraction. In that study, squalene showed the highest solubility among all other components due to its nonpolar characteristic and smaller molecular size. Thus, the $\mathrm{SC}-\mathrm{CO}_{2}$ technique has the potential to produce two types of value-added oils from palm-pressed mesocarp fiber.

\section{Prospect and Limitation of SC-CO $\mathrm{CO}_{2}$ in Palm Oil Industry}

Laboratory scale attempts are always the primary steps to establish a new technique or methodology. As an attempt to industrialization of SFE technology, SCF has been applied to a lot of extraction purposes at the laboratory scale and its suitability has been reported. Casas et al. [89], reported that SFE can be applied from a laboratory scale to large industrial scale (less than a gram to tons of raw materials). Before using in the industry, a method or technology needs scaling-up from laboratory to pilot plants. Successful scale up means the maintenance of quality of products obtained after scale up. Typically before SFE is employed at the industrial scale, a pilot plant is set up to test the soundness of the system incorporating laboratory data in the design. The easy scale-up procedure for SFE processes consists of two steps: the first is to perform small scale assays to define the optimal extraction conditions through a screening of operational parameters. The second step involves the selection of the scale-up method based on the kinetic limiting factors [90]. Reverchon et al. [91], compared lab-scales and pilot scales in supercritical assisted atomization. In most cases the parameters to be evaluated are extraction pressure, $\mathrm{CO}_{2}$ flow rate and particle size. There are several mass transfer models to explain the extraction curves among which logistic model, diffusion model and Sovová model are the most convenient [92,93]. Furthermore, Oliveira et al. [94] reviewed significant models such as the linear driving force, shrinking core, broken and intact cells (BIC), and the combination of BIC and shrinking core models.

Recently, the kinetics and mathematical model described by Mezzomo et al. [90], for scaling-up of the SFE method was used for extraction of peach almond oil. This SFE modeling defined some useful parameters for process design, especially in equipment dimensions, solvent flow rate and particle size determination. Casas et al. [89], successfully established scaling-up of the $\mathrm{SC}-\mathrm{CO}_{2}$ method for the 
extraction of bioactive compounds from the sunflower leaves, where the authors investigated the influence of the extraction time at various flow rates of $\mathrm{SC}-\mathrm{CO}_{2}$ solvent. Aro et al. [95], reported a study using pilot scale SFE equipped with two extraction chambers, where one chamber was for antisolvent process for the production of pure phospholipids from egg yolk. Pettinello et al. [96], scaled up a supercritical fluid chromatography for purification of eicosapentaenoic acid ethyl ester (EPA-EE) where the pilot scale purity of EPA-EE reduced from $95 \%$ (bench scale) to $93 \%$.

In the near future studies number-up could be used over the scaling-up method using geometric, dynamic, and kinematic similarities. This method is introduced by Oldshue in 1983 [97]. Figure 2 shows the overall concept of Number-up method.

Figure 2. Scale-up to larger, geometric full-scale system.
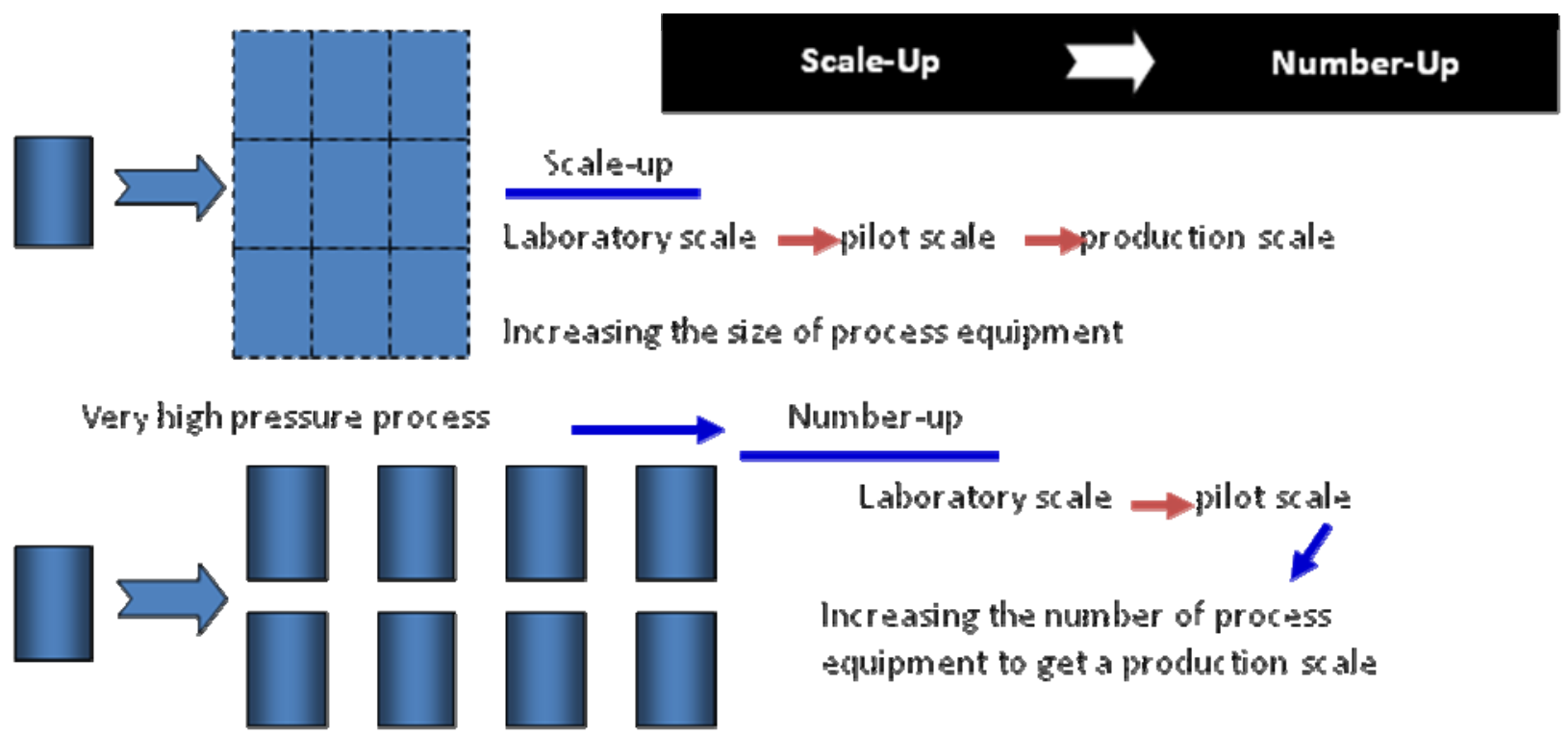

Parallel or series

Palm oil is the oil with the lowest production costs, considering that palm oil is now the "marginal" oil [98]. Further decrease in production cost by using SFE will push palm oil one step forward in taking over the world market. The move away from trans-fatty acids also favors palm oil, because it can be used without hydrogenation as the solid fat component in many formulations [99].

As discussed in earlier sections, SFE could be advantageous for fractionating different constituents of palm oil and $\mathrm{PKO}$ and be blended again in desired ratios to formulate different types of palm oil according to the market demands. $\mathrm{SC}-\mathrm{CO}_{2}$, being a cheaper recyclable solvent, will ensure it will not be costly to produce the desired fractions and bears no threat to health and the environment. The major hurdle to the application of SFE or SC- $\mathrm{CO}_{2}$ in palm oil industry is its instrumentation on an industrial scale. Another problem is the maintenance of the SFE equipment which is somewhat costly as gas-leakage can be frequent during high pressure operation. Attention should be paid while constructing the heavy duty equipment for use in the industry. It is also important to keep in mind during construction of the equipment to link a supercritical fluid chromatography to SFE equipment to be used for special purposes to concentrate desired components. By this time SFE has been established to industrial scale in essential oil extraction from different spices and in extraction of some pharmaceutical or 
phytochemicals from different plant parts. Once the industry adopts SFE equipment in palm oil extraction, the process can appear cost-effective or more profitable than the conventional methods.

\section{Supercritical Fluid Extractions of Other Oil Types from Various Sources}

Recently, Temelli et al. [25], reported and classified specialty oils such as nut oils (almond, hazelnut, peanut, pecan, pistachio, and walnut), seed oils (apricot, borage, cherry, evening primrose, flax, grape, hiprose, pumpkin, sea buckthorn, sesame, etc.), cereal oils (amaranth, oat, rice bran, and wheat germ), and fruits and vegetables oils (buriti fruit, carrot, cloudberry, olive husk, and tomato), which have been extracted using $\mathrm{SC}-\mathrm{CO}_{2}$. The major advantage of the $\mathrm{SC}-\mathrm{CO}_{2}$ extraction method for specialty oils is preserving the unique flavour and aroma while volatile aroma compounds are often lost during traditional solvent extraction processing. Specialty oils contain high level of bioactive components, such as polyunsaturated fatty acids, tocopherols, tocotrienols, phytosterols, carotenoids and squalene. These components play tremendously positive roles in human health. Due to the public awareness as well as demand food industries are always looking for such kind of oils which are naturally extracted. Meanwhile, $\mathrm{SC}-\mathrm{CO}_{2}$ extraction has been demonstrated the best method for bioactive lipid components in the literature [100-103].

Essential fatty acids such as linoleic acid are necessary for human metabolism and cannot the synthesized inside the human body. Essential fatty acids must be supplied externally from the diet. Essential fatty acids play an important role in the formation of cell membranes, and the proper development and functioning of the brain and nervous system. Hormone-like substances called eicosanoids produced by essential fatty acid are responsible for regulating blood pressure and viscosity, vasoconstriction and immune and inflammatory responses [104]. It has been well demonstrated that fatty acid deficiency is associated with several human diseases. Fatty acid consumption has large health benefits such as reduced inflammatory diseases [105]. SC- $\mathrm{CO}_{2}$ has been extensively used to obtain oil as well as fatty acid components from various seeds: apricot [106], palm kernel [43], canola [107], rapeseed, soybean, and sunflower [108], jojoba [109], sesame [110], parsley [111], amaranth [112], borage [113], flax [114], and grape [115]. Moreover, oils have also been extracted from several nuts such as almond [116], walnut [100], peanuts [117], pistachio [118] and acorn [119]. Recently, several researchers have investigated $\mathrm{SC}-\mathrm{CO}_{2}$ extraction of plants oil such as Ferulago angulata [120], Sacha inchi [121], chia [16], Anastatica hierochuntica [122]. SC-CO extraction of oils and the impact of various extraction parameters were also reported by many reporters in the literature. Supercritical fluid extraction of oils from various sources in different studies is shown in Table 7.

Table 7. Summary of oil extraction from various natural sources using $\mathrm{SC}-\mathrm{CO}_{2}$.

\begin{tabular}{lccccc}
\hline Samples & Scientific name & Extract & $\begin{array}{c}\text { Oil yield } \\
(\mathbf{w t .} \%)\end{array}$ & $\begin{array}{c}\text { Pressure/Temperature } \\
(\mathbf{M P a}) / \mathbf{T}\left({ }^{(} \mathbf{C}\right)\end{array}$ & References \\
\hline $\begin{array}{l}\text { Seeds } \\
\text { Palm Kernel }\end{array}$ & Elaeis guineensis & $\begin{array}{c}\text { Fatty acid } \\
\text { composition }\end{array}$ & 49 & $20.7-48.3 / 40-80$ & {$[43]$} \\
\hline
\end{tabular}


Table 7. Cont.

\begin{tabular}{|c|c|c|c|c|c|}
\hline Samples & Scientific name & Extract & $\begin{array}{l}\text { Oil yield } \\
(\text { wt. \%) }\end{array}$ & $\begin{array}{c}\text { Pressure/Temperature } \\
(\mathbf{M P a}) / \mathbf{T}\left({ }^{\circ} \mathbf{C}\right)\end{array}$ & References \\
\hline Peach seed & Prunus persica & $\begin{array}{l}\text { Oils, fatty acid } \\
\text { composition, } \\
\text { tocopherols }\end{array}$ & 70 & $15.0-19.8 / 40-51$ & [104] \\
\hline Apricot & $\begin{array}{c}\text { Prunus } \\
\text { armeniaca } \mathrm{L} .\end{array}$ & Oils & & $30-60 / 40-70$ & [106] \\
\hline Canola seed & Brassica napus & Seed oil & 19.49 & $20-25 / 40-60$ & [107] \\
\hline Rapeseeds & $\begin{array}{c}\text { Brassica } \\
\text { napus } \text { var. Rapora }\end{array}$ & Seed oil & 39.3 & $32-35 / 17-40$ & [108] \\
\hline Soybean & $\begin{array}{l}\text { Glycine max var. } \\
\text { Corsoy }\end{array}$ & Seed oil & 16.6 & $28-30 / 20-40$ & [108] \\
\hline Sunflower & $\begin{array}{c}\text { Helianthus } \\
\text { annuus var. } \\
\text { Fransol }\end{array}$ & Seed oil & 36 & $25-35 / 20-50$ & [108] \\
\hline Jojoba seed & $\begin{array}{l}\text { Simmondsia } \\
\text { chinensis }\end{array}$ & Seed oil & 80 & $25-45 / 67-90$ & [109] \\
\hline Sesame seed & $\begin{array}{c}\text { Sesamun } \\
\text { indicum L. }\end{array}$ & Seed oil & 35 & $19-25 / 40-60$ & [110] \\
\hline Parsley & $\begin{array}{c}\text { Petroselinum } \\
\text { sativum Hoffm. }\end{array}$ & Seed oil & & $10-15 / 35-45$ & [111] \\
\hline Amaranth seed & $\begin{array}{c}\text { Amaranth } \\
\text { cruentus }\end{array}$ & lipids & 7.95 & $10-30 / 35-50$ & [112] \\
\hline Borage seed & B. officinalis L. & Seed oil & 29 & $5-35 / 10-60$ & [113] \\
\hline Flaxseed & $\begin{array}{c}\text { Linum } \\
\text { usitatissimum L. }\end{array}$ & Seed oil & 35.3 & $30 / 50$ & [114] \\
\hline Grape seed & Vitis vinifera & $\begin{array}{l}\text { Fatty acid } \\
\text { composition }\end{array}$ & 13.6 & & [115] \\
\hline Cardamom & $\begin{array}{c}\text { Elettaria } \\
\text { cardamomum } \\
\text { Maton }\end{array}$ & $\begin{array}{c}\text { Fatty acids, } \\
\text { tocopherols } \\
\text { Carotenoids, } \\
\text { Chlorophylls, } \\
\text { volatile } \\
\text { constituents }\end{array}$ & 6.65 & $10-80 / 25-35$ & [123] \\
\hline Cottonseed & Gossypium sp. & Oil & 17.26 & $35-55 / 60-80$ & [124] \\
\hline Kenaf seeds & $\begin{array}{c}\text { Hibiscus } \\
\text { cannabinus L. }\end{array}$ & Seed oil & 20.18 & $20-60 / 40-80$ & [125] \\
\hline Passiflora seed & $\begin{array}{c}\text { P. edulis Sims } \\
\text { var. edulis }\end{array}$ & Seed oil & 25.83 & $17-33 / 47-63$ & [126] \\
\hline $\begin{array}{l}\text { Pomegranate } \\
\text { seed }\end{array}$ & $\begin{array}{c}\text { Punica } \\
\text { granatum L. }\end{array}$ & $\begin{array}{l}\text { Fatty acid } \\
\text { composition }\end{array}$ & 3.39 & $20-35 / 40-60$ & [127] \\
\hline Pumpkin & $\begin{array}{c}\text { Cucurbita } \\
\text { maxima }\end{array}$ & Seed oil & 30.7 & $15-35 / 35-75$ & [128] \\
\hline Rosehip seed & Rosa canina L. & Seed oil & 15.93 & $15-45 / 40-80$ & [129] \\
\hline
\end{tabular}


Table 7. Cont.

\begin{tabular}{|c|c|c|c|c|c|}
\hline Samples & $\begin{array}{c}\text { Scientific } \\
\text { name }\end{array}$ & Extract & $\begin{array}{l}\text { Oil yield } \\
(\text { wt. \%) }\end{array}$ & $\begin{array}{c}\text { Pressure/Temperature } \\
(\mathbf{M P a}) / \mathbf{T}\left({ }^{\circ} \mathbf{C}\right)\end{array}$ & References \\
\hline Sea buckthorn & $\begin{array}{c}\text { Hippophaё } \\
\text { thamnoides } \mathrm{L} .\end{array}$ & $\begin{array}{l}\text { Oil, Vitamine E, } \\
\text { Carotenoids }\end{array}$ & & $20-40 / 40-60$ & [130] \\
\hline Chia seed & $\begin{array}{c}\text { Salvia } \\
\text { hispanica L. }\end{array}$ & Seed oil & 92.8 & $25-45 / 40-80$ & [16] \\
\hline $\begin{array}{l}\text { Sacha inchi } \\
\text { seed }\end{array}$ & $\begin{array}{l}\text { Plukenetia } \\
\text { volubilis } L .\end{array}$ & $\begin{array}{l}\text { Seed oil, } \\
\text { Tocopherols, } \\
\text { Carotene }\end{array}$ & 50.1 & $30-40 / 40-60$ & [121] \\
\hline $\begin{array}{l}\text { Pithecellobium } \\
\text { jiringan seed }\end{array}$ & & $\begin{array}{l}\text { Fatty acid, } \\
\text { vitamin E, } \\
\text { flavonoids }\end{array}$ & & $60 / 80$ & [131] \\
\hline Aniseed & $\begin{array}{l}\text { Pimpinella } \\
\text { anisum } \mathrm{L} \text {. }\end{array}$ & Essential oil & $10.67 \%$ & $8-18 / 30$ & [132] \\
\hline Coriander seed & $\begin{array}{l}\text { Coriandrum } \\
\text { satium } \mathrm{L} \text {. }\end{array}$ & Essential oil & & $20-30 / 35$ & [133] \\
\hline Cherry seeds & Prunus avium $\mathrm{L}$. & Essential oil & & $18-22 / 39-60$ & [134] \\
\hline $\begin{array}{l}\text { Evening } \\
\text { primrose }\end{array}$ & $\begin{array}{l}\text { Oenothera } \\
\text { biennis L. }\end{array}$ & Essential oil & & 20-70/40-60 & [135] \\
\hline Guava & $\begin{array}{c}\text { Psidium } \\
\text { guajava } \mathrm{L} .\end{array}$ & Seed oil & 17.30 & $10-30 / 40$ & [136] \\
\hline $\begin{array}{l}\text { Orange peel } \\
\text { Nuts }\end{array}$ & & Essential oil & & $8-28 / 20-50$ & [137] \\
\hline Walnut & $\begin{array}{c}\text { Juglans regia } \\
\text { L. var. } \\
\text { Franquette }\end{array}$ & $\begin{array}{l}\text { Fatty acid } \\
\text { composition }\end{array}$ & 19 & $20-40 / 50-70$ & [100] \\
\hline Almond & & Almon oil & 50 & $35 / 40$ & [116] \\
\hline Pistachio & Pistacia Vera L. & Essential oil & 66 & $20.7-34.5 / 50-70$ & [118] \\
\hline Acorn & $\begin{array}{c}\text { Quercus } \\
\text { rotundifolia } \mathrm{L} \text {. }\end{array}$ & $\begin{array}{l}\text { Fatty acid } \\
\text { composition }\end{array}$ & & $12-21 / 35-60$ & [119] \\
\hline Coconut & Cocos nucifera $\mathrm{L}$. & $\begin{array}{l}\text { Fatty acid } \\
\text { composition }\end{array}$ & & $20.7-34.5 / 40-80$ & [138] \\
\hline $\begin{array}{l}\text { Hazelnut } \\
\text { Cereal oils }\end{array}$ & & Oil & 33 & $15-60 / 40-60$ & [139] \\
\hline Wheat germ & & $\begin{array}{l}\text { Fatty acid } \\
\text { composition }\end{array}$ & 10.15 & $20-35 / 40-60$ & [140] \\
\hline Rice brain & & $\begin{array}{l}\text { Fatty acid } \\
\text { composition }\end{array}$ & 22 & $17-31 / 1-60$ & [141] \\
\hline Oat & & $\begin{array}{l}\text { Digalactosyldiacy } \\
\text { lglycerols }\end{array}$ & & $40 / 50-70$ & [142] \\
\hline
\end{tabular}


Table 7. Cont.

\begin{tabular}{|c|c|c|c|c|c|}
\hline Samples & $\begin{array}{c}\text { Scientific } \\
\text { name }\end{array}$ & Extract & $\begin{array}{l}\text { Oil yield } \\
\text { (wt. \%) }\end{array}$ & $\begin{array}{c}\text { Pressure/Temperature } \\
(\mathrm{MPa}) / \mathrm{T}\left({ }^{\circ} \mathbf{C}\right)\end{array}$ & References \\
\hline \multicolumn{6}{|l|}{ Plants } \\
\hline $\begin{array}{l}\text { Anastatica } \\
\text { hierochuntica }\end{array}$ & $\begin{array}{c}\text { Anastatica } \\
\text { hierochuntica }\end{array}$ & $\begin{array}{c}\text { hexadecanoic } \\
\text { acid, 9,12- } \\
\text { octadecadienoic } \\
\text { acid, heneicosane, } \\
\text { heptacosane }\end{array}$ & 1.15 & $22-46 / 32-46$ & [122] \\
\hline Ferulago & & Essential oil & 1.0 & $9-19 / 35-55$ & [120] \\
\hline \multicolumn{6}{|l|}{ Angulata } \\
\hline Vetiver roots & $\begin{array}{c}\text { Vetiveria } \\
\text { zizanioides } \mathrm{L} .\end{array}$ & Essential oil & 5.90 & $10-19 / 40-50$ & [143] \\
\hline $\begin{array}{l}\text { Nitraria } \\
\text { tangutorum }\end{array}$ & & Seed Oil & & $10-30 / 30-50$ & [144] \\
\hline yellow horn & $\begin{array}{c}\text { Xanthoceras } \\
\text { sorbifolia } \\
\text { Bunge }\end{array}$ & Seed oil & 61.28 & $15-35 / 30-60$ & [145] \\
\hline Rose geranium & Pelargonium sp. & Essential oil & 77.82 & $8-16 / 40-100$ & [146] \\
\hline $\begin{array}{l}\text { Silkworm } \\
\text { pupae }\end{array}$ & & Essential oil & 29.73 & $15-35 / 30-50$ & [147] \\
\hline Sage leaves & $\begin{array}{c}\text { Salvia } \\
\text { Officinalis L. }\end{array}$ & Essential oil & 1.35 & $8-10 / 45-60$ & [2] \\
\hline Lovage & $\begin{array}{c}\text { Levisticum } \\
\text { officinale Koch. }\end{array}$ & Essential oil & 4.92 & $8-35 / 40-50$ & [148] \\
\hline Chamomile & $\begin{array}{c}\text { Chamomilla } \\
\text { recutita }[\mathrm{L} .] \\
\text { Rauschert }\end{array}$ & Essential oil & 4.33 & $10-20 / 30-40$ & [149] \\
\hline Lemongrass & $\begin{array}{c}\text { Cymbopogon } \\
\text { citratus }\end{array}$ & Essential oil & $1-2 \%$ & $8.5-12 / 23-50$ & {$[150]$} \\
\hline Black pepper & Piper nigrun L. & Essential oil & 70 & $15-30 / 30-50$ & [151] \\
\hline
\end{tabular}

\section{Conclusions}

Supercritical fluid technology has made significant advances for the extraction of oil from natural sources over the past 20 years. The palm oil industry is a prospective field for the application of SFE method using $\mathrm{SC}-\mathrm{CO}_{2}$ as a solvent that can minimize wastewater compared to conventional mechanical extraction. It is a cost effective technique at both the laboratory- and industrial-scale for the extraction of palm oil, palm kernel oil and minor components such as carotenes, tocopherols, and more from palm oil and palm leaves. Extraction of tocopherols from leaves taken off the palm trees while collecting the fruits may be a route to be evaluated further. In general, tocopherol levels in palm leaves were not high enough to allow an economic industrial-scale extraction. SFE can also act as a sterilizer for palm fiber oil, a by-product of palm oil extraction. Besides, the residual palm kernel meal obtained from SFE process using $\mathrm{CO}_{2}$ can be a good, low fiber animal feed. Although the technique is struggling with the cost-effectiveness factors in the case of low-volume products, it is overcoming this 
limitation day by day and promising economic benefits. Based on this review, it can be concluded that SFE is the best method for exploitation in the extraction of palm oil on an industrial scale.

\section{Acknowledgment}

This work was supported by the Universiti Sains Malaysia (USM fellowship)

\section{References}

1. Herrero, M.; Mendiola, J.A.; Cifuentes, A.; Ibáñez, E. Supercritical fluid extraction: Recent advances and application. J. Chromatogr. A 2010, 1217, 2495-2511.

2. Reverchon, E.; Taddeo, R. Extraction of sage oil by supercritical $\mathrm{CO}_{2}$ : Influence of some process parameters. J. Supercrit. Fluids 1995, 8, 302-309.

3. Tello, J.; Viguera, M.; Calvo, L. Extraction of caffeine from Robusta coffee (Coffee canephora var. Robusta) husks using supercritical carbon dioxide. J. Supercrit. Fluids 2011, 59, 53-60.

4. Korhonen, H. Technology options for new nutritional concepts. Int. J. Dairy Technol. 2002, 55, 2.

5. Hultin, H.O. Oxidation of lipids in seafoods. In Seafoods: Chemistry, Processing Technology and Quality; Shahidi, F., Botta, J.R., Eds.; Chapman \& Hall: London, UK, 1994; pp. 49-74.

6. Staby, A.; Mollerup, J. Separation of constituents of fish oil using supercritical fluids: A review of experimental solubility, extraction, and chromatographic data. Fluid Phase Equilib. 1993, 91, 349-386.

7. List, G.R.; King, J.W.; Johnson, J.H.; Warner, K.; Mounts, T.L. Supercritical $\mathrm{CO}_{2}$ degumming and physical refining of soybean oil. J. Am. Oil Chem. Soc. 1993, 70, 5.

8. Ooi, C.K.; Bhaskar, A.; Yener, M.S.; Tuan, D.Q.; Hsu, J.; Rizvi, S.S.H. Continuous supercritical carbon dioxide processing of palm oil. J. Am. Oil Chem. Soc. 1996, 73, 233-237.

9. Manan, Z.A.; Siang, L.C.; Mustapa, A.N. Development of a new process for palm oil refining based on supercritical fluid extraction technology. Ind. Eng. Chem. Res. 2009, 48, 5420-5426.

10. Yoon, J.; Han, B.-S.; Kang, Y.-C.; Kim, K.H.; Jung, M.Y.; Kwon, Y.A. Purification of used fying oil by supercritical carbon dioxide extraction. Food Chem. 2000, 71, 275-279.

11. Majewski, W.; Mengal, P.; Perrut, M.; Ecalard, J.P. Supercritical fluid fractionation of butter oil. In Proceedings of Supercritical Fluid Processing of Biomaterials: Basics of Process Design and Applications Symposium, Toronto, ON, Canada, 29 September-4 October 1991.

12. Kwon, Y.A.; Chao, R.R. Fractionation and cholesterol reduction of beef tallow by supercritical $\mathrm{CO}_{2}$ extraction. Food Biotechnol. 1995, 4, 234-242.

13. Akgerman, A.; Roop, R.K.; Hess, R.K.; Yeo, S.D. Environmental application of supercritical extraction. In Supercritical Fluid Technology-Reviews on Modern Theory and Application; Bruno, T.J., Ely, J.F., Eds.; CRC Press: Boca Raton, FL, USA, 1991; p. 479.

14. Erkey, C.; Madras, G.; Orejuela, M.; Akgerman, A. Supercritical carbon dioxide of organics from soil. Environ. Sci. Technol. 1993, 27, 1225-1231.

15. Salgin, U.; Yildiz, N.; Köroğlu, F.; Çalimli, A. A parametric study of phenolic compounds desorption performance from organobentonite by supercritical fluids. J. Supercrit. Fluids 2007, 39, 296-303. 
16. Ixtaina, V.Y.; Vega, A.; Nolasco, S.M.; Tomás, M.C.; Gimeno, M.; Bárzana, E.; Tecante, A. Supercritical carbon dioxide extraction of oil from Mexican chia seed (Salvia hispanica L.): Characterization and process optimization. J. Supercrit. Fluids 2010, 55, 192-199.

17. Nik Norulaini, N.A.; Setianto, W.B.; Zaidul, I.S.M.; Nawi, N.A.; Azizi, C.Y.M.; Mohd Omar, A.K. Effects of supercritical carbon dioxide extraction parameters on virgin coconut oil yield and medium-chain triglyceride content. Food Chem. 2009, 116, 193-197.

18. Zaidul, I.S.M.; Norulaini, N.A.N.; Mohd Omar, A.K. Separation/fractionation of triglycerides in terms of fatty acid constituents in palm kernel oil using supercritical $\mathrm{CO}_{2}$. J. Sci. Food Agric. 2006, 86, 1138-1145.

19. Létisse, M.; Rozières, M.; Hiol, A.; Sergent, M.; Comeau, L. Enrichment of EPA and DHA from sardine by supercritical fluid extraction without organic modifier I. Optimization of extraction conditions. J. Supercrit. Fluids 2006, 38, 27-36.

20. Sahena, F.; Zaidul, I.S.M.; Jinap, S.; Yazid, A.M.; Khatib, A.; Norulaini, N.A.N. Fatty acid compositions of fish oil extracted from different parts of Indian mackerel (Rastrelliger kanagurta) using various techniques of supercritical $\mathrm{CO}_{2}$ extraction. Food Chem. 2010, 120, 879-885.

21. Chuang, M.-H.; Brunner, G. Concentration of minor components in crude palm oil. J. Supercrit. Fluids 2006, 37, 151-156.

22. Ibáñez, E.; Palacios, J.; Señoráns, F.J.; Santa-María, G.; Tabera, J.; Reglero, G. Isolation and separation of tocopherols from olive by-products with supercritical fluids. J. Am. Oil Chem. Soc. 2000, 77, 2.

23. Pourmortazavi, S.M.; Hajimirsadeghi, S.S. Supercritical fluid extraction in plant essential and volatile oil analysis. J. Chromatogr. A 2007, 1163, 2-24.

24. Liu, W.; Fu, Y.-J.; Zu, Y.-G.; Tong, M.-H.; Wu, N.; Liu, X.-L.; Zhang, S. Supercritical carbon dioxide extraction of seed oil from Opuntia dillenii Haw and its antioxidant activity. Food Chem. 2009, 114, 334-339.

25. Temelli, F. Perspectives on supercritical fluid processing of fats and oils. J. Supercrit. Fluids 2009, 47, 583-590.

26. Machmudah, S.; Kondo, M.; Sasaki, M.; Goto, M.; Munemasa, J.; Yamagata, M. Pressure effect in supercritical $\mathrm{CO}_{2}$ extraction of plant seeds. J. Supercrit. Fluids 2008, 44, 301-307.

27. Fiori, L.; Basso, D.; Costa, P. Seed oil supercritical extraction: Particle size distribution of the milled seeds and modeling. J. Supercrit. Fluids 2008, 47, 174-181.

28. Langa, E.; Cacho, J.; Palavra, A.M.F.; Burillo, J.; Mainar, A.M.; Urieta, J.S. The evolution of hyssop oil composition in the supercritical extraction curve: Modelling of the oil extraction process. J. Supercrit. Fluids 2009, 49, 37-44.

29. Casas, L.; Mantell, C.; Rodríguez, M.; Torres, A.; Macías, F.A.; de la Ossa, E.M. Extraction of natural compounds with biological activity from sunflower leaves using supercritical carbon dioxide. Chem. Eng. J. 2009, 152, 301-306.

30. Bocevska, M.; Sovová, H. Supercritical $\mathrm{CO}_{2}$ extraction of essential oil from yarrow. J. Supercrit. Fluids 2007, 40, 360-367. 
31. Diaz-Maroto, M.C.; Perez-Coello, S.; Cabezudo, M.D. Supercritical carbon dioxide extraction of volatiles from spices comparison with simultaneous distillation-extraction. J. Chromatogr. A 2002, 947, 23-29.

32. Reverchon, E.; Marrone, C. Modeling and simulation of the supercritical $\mathrm{CO}_{2}$ extraction of vegetable oils. J. Supercrit. Fluids 2001, 19, 161-175.

33. Gracia, I.; García, M.T.; Rodríguez, J.F.; Fernández, M.P.; de Lucas, A. Modelling of the phase behaviour for vegetable oils at supercritical conditions. J. Supercrit. Fluids 2009, 48, 189-194.

34. Mohamed, R.S.; Mansoori, G.A. The Use of Supercritical Fluid Extraction Technology in Food Processing; Featured Article-Food Technology Magazine, The World Markets Research Centre: London, UK, June 2002.

35. Gómez, A.M.; López, C.P.; Dela Ossa, E.M. Recovery of grape seed oil by liquid and supercritical carbon dioxide extraction: A comparison with conventional solvent extraction. Chem. Eng. J. 1996, 61, 227-231.

36. Rial-Otero, R.; Gaspara, E.M.; Moura, I.; Capeloa, J.L. Gas chromatography mass spectrometry determination of acaricides from honey after a new fast ultrasonic-based solid phase micro-extraction sample treatment. Talanta 2007, 71, 1906-1914.

37. Rizvi, S.S.H.; Yu, Z.R.; Bhaskar, A.R.; Raj, C.C.B. Fundamentals of processing with supercritical fluid. In Supercritical Fluid Processing of Food and Biomaterials; Rizvi, S.S.H., Ed.; Chapman and Hall: Glasgow, UK, 1994; pp. 1-26.

38. Zaidul, I.S.M.; Norulaini, N.A.N.; Mohd Omar, A.K.; Sato, Y.; Smith, R.L., Jr. Separation of palm kernel oil from palm kernel with supercritical carbon dioxide using pressure swing technique. J. Food Eng. 2007, 81, 419-428.

39. Berger, T.A.; Fogleman, K.; Staats, T.; Bente, P.; Crocket, I.; Farrell, W.; Osonubi, M. The development of a semi-preparatory scale supercritical fluid chromatograph for high-throughput purification of 'combi-chem' librariesn. J. Biochem. Biophys. Methods 2000, 43, 87-111.

40. Malaysian Palm Oil Board (MPOB). Report of Malaysian Palm Oil Research Board (Palm Oil Research Board of Malaysia); MPOB: Bangi, Malaysia, 2008.

41. Ibrahim, N.A.; Kuntom, A.; Sue, T.T.; Lin, S.W. Current status of Malaysian crude palm kernel oil characteristics. Oil Palm Bull. 2003, 47, 15-27.

42. Crutchfield, J. Indonesia: Palm Oil Production Prospects Continue to Grow; United States Department of Agriculture, FAS: Washington, DC, USA, 2007; pp. 1-4.

43. Zaidul, I.S.M.; Norulaini, N.A.N.; Mohd Omar, A.K.; Smith, R.L., Jr. Supercritical carbon dioxide (SC-CO2) extraction of palm kernel oil from palm kernel. J. Food Eng. 2007, 79, 1007-1014.

44. Sambanthamurthi, R.; Sundram, K.; Tan, Y.-A. Chemistry and biochemistry of palm oil. Prog. Lipid Res. 2000, 39, 507-558.

45. Chaiseri, S.; Dimick, P.S. Dynamic crystallization of cocoa butter I. Characterization of simple lipids in rapid- and slow-nucleating cocoa butters and their seed crystals. J. Am. Oil Chem. Soc. 1995, 72, 1491-1496.

46. Tang, T.S.; Teoh, P.K. Palm kernel extraction-The Malaysian Experience. J. Am. Oil Chem. Soc. 1985, 62, 254-258.

47. Suria, M.A.Y. Refining and Downstream Processing of Palm and Palm Kernel Oils. Lectures on Palm Oil and Its Uses. 21st Palm Oil Familiarization Programme. 2001; pp. 41-66. 
48. Canfield, L.M. $\beta$-carotenoid metabolites: Potential importance to human health. Malays. Oil Sci. Technol. 1995, 4, 43-46.

49. Lenfant, C.; Thyrion, F.C. Extraction of carotenoids from palm oil. II. Isolation method. $O C L$ 1996, 3, 294-307.

50. Lau, H.L.N.; Choo, Y.M.; Ngan, M.A.; Chuah, C.H. Production of refined carotene-rich palm oil from palm mesocarp (elaeis guineensis) using supercritical carbon dioxide. J. Food Lipids 2007, 14, 396-410.

51. Lau, H.L.N.; Choo, Y.M.; Ma, A.N.; Chuah, C.H. Quality of residual oil from palm-pressed mesocarp fiber (Elaeis guineensis) using supercritical $\mathrm{CO}_{2}$ with and without ethanol. J. Am. Oil Chem. Soc. 2006, 83, 893-898.

52. Wei, P.C.; May, C.Y.; Ngan, M.A.; Hock, C.C. Supercritical fluid extraction of palm carotenoids. Am. J. Environ. Sci. 2005, 14, 264-269.

53. Choo, Y.-M.; Yap, S.-C.; Ooi, C.-K.; Ma, A.-N.; Goh; S.-H.; Ong, A.S.-H. Recovered oil from palm pressed fiber: A good source of natural carotenoids, vitamin $\mathrm{E}$ and sterols. J. Am. Oil Chem. Soc. 1996, 73, 599-602.

54. Macías-Sánchez, M.D.; Mantell, C.; Rodríguez, M.; Martínez de la Ossa, E.; Lubián, L.M.; Montero, O. Supercritical fluid extraction of carotenoids and chlorophyll a from Nannochloropsis gaditana. J. Food Eng. 2005, 66, 245-251.

55. Machmudah, S.; Zakaria; Winardi, S.; Sasaki, M.; Goto, M.; Kusumoto, N.; Hayakawa, K. Lycopene extraction from tomato peel by-product containing tomato seed using supercritical carbon dioxide. J. Food Eng. 2012, 108, 290-296.

56. Avalos, J.; Cerdá-Olmedo, E. Fungal carotenoid production. In Handbook of Fungal Biotechnology, 2nd ed.; Arora, D.K., Ed.; Marcel Dekker Inc.: New York, NY, USA, 2004; Volume 1, pp. 367-378.

57. Lau, H.L.N.; Choo, Y.M.; Ma, A.N.; Chuah, C.H. Selective extraction of palm carotene and vitamin $\mathrm{E}$ from fresh palm-pressed mesocarp fiber (Elaeis guineensis) using supercritical $\mathrm{CO}_{2}$. J. Food Eng. 2008, 84, 289-296.

58. Thyrion, F.C. The production of natural antioxidants (other than vitamin E). In Lipid Synthesis and Manufacture; Gunstone, F.D., Ed.; CRC Press: Boca Raton, FL, USA, 1999; p. 268.

59. Choudhari, S.M.; Singhal, R.S. Supercritical carbon dioxide extraction of lycopene from mated cultures of Blakeslea trispora NRRL 2895 and 2896. J. Food Eng. 2008, 89, 349-354.

60. Friedrich, W. Handbuch der Vitamine; Urban \& Schwarzenberg: Munchen, Germany, 1987.

61. Garewall, H.G. Antioxidant and Disease Prevention; CRC Press: Boca Raton, FL, USA, 1997.

62. Theriault, A.; Chao, J.-T.; Wang, Q.; Gapor, A.; Adeli, K. Tocotrienol: A review of its therapeutic potential. Clin. Biochem. 1999, 3, 309-319.

63. Netscher, T. Synthesis and production of vitamin E. In Lipid Synthesis and Manufacture; Gunstone, F.D., Ed.; CRC Press: Boca Raton, FL, USA, 1999; p. 250.

64. Siew, W.L.; Ng, W.L. Effect of diglycerides on the crystallisation of palm oleins. J. Sci. Food Agric. 1996, 71, 496-500.

65. Rao, C.V.; Newmark, H.L.; Reddy, B.S. Chemopreventive effect of squalene on colon cancer. Carcinogenesis 1998, 19, 287-290. 
66. Smith, T.J.; Yang, G.Y.; Seril, D.N.; Liao, J.; Kim, S. Inhibition of 4-(methylnitrosamino)-1-(3pyridyl)-1-butanone-induced lung tumourigenesis by dietary olive oil and squalene. Carcinogenesis 1998, 19, 703-706.

67. Berger, K.G. Food Uses of Palm Oil; MPOPC Palm Oil Information Series: Kuala Lumpur, Malaysia, 1996; p. 25.

68. Pantzaris, T.P. Pocketbook of Palm Oil Uses, 5th ed.; Malaysian Palm Oil Board (MPOB): Bangi, Malaysia, 2000; pp. 102-109.

69. Mohtar, Y.; Tang, T.S.; Salmiah, A. Characteristics and properties of commercial fatty acids from some Malaysian manufacturers. PORIM Technol. 1998, 21, 34.

70. Salmiah, A. Non-Food Uses of Palm Oil and Palm Kernel Oil; MPOPC Palm Oil Information Series: Kuala Lumpur, Malaysia, 2000; p. 24.

71. Norulaini, N.A.N.; Ahmad, A.; Omar, F.M.; Ashur, A.S.B.; Zaidul, I.S.M.; Mohd Omar, A.K. Sterilization and extraction of palm oil from screw pressed palm fruit fiber using supercritical carbon dioxide. Sep. Purif. Technol. 2008, 60, 272-277.

72. Zaidul, I.S.M.; Norulaini, N.A.N.; Mohd Omar, A.K.; Smith, R.L., Jr. Supercritical carbon dioxide (SC-CO2) extraction and fractionation of palm kernel oil from palm kernel as cocoa butter replacers blend. J. Food Eng. 2006, 73, 210-216.

73. Zaidul, I.S.M.; Norulaini, N.A.N.; Mohd Omar, A.K.; Smith, R.L., Jr. Blending of supercritical carbon dioxide (SC-CO2) extracted palm kernel oil fractions and palm oil to obtain cocoa butter replacers. J. Food Eng. 2007, 78, 1397-1409.

74. Norulaini, N.A.N.; Zaidul, I.S.M.; Anuar, O.; Mohd Omar, A.K. Supercritical enhancement for separation of lauric acid and oleic acid in palm kernel oil (PKO). Sep. Purif. Technol. 2004, 35, 55-60.

75. Norulaini, N.A.N.; Zaidul, I.S.M.; Anuar, O.; Mohd Omar, A.K. Supercritical reduction of lauric acid in palm kernel oil (PKO) to produce cocoa butter equivalent (CBE). J. Chem. Eng. Jpn. 2004, 37, 194-203.

76. Hassan, M.N.; Ab Rahman, N.N.; Anuar, B.O.; Ibrahim, M.H.; Mohd Omar, A.K. Simple fractionation through the supercritical carbon dioxide extraction of palm kernel oil. Sep. Purif. Technol. 2000, 19, 113-120.

77. Markom, M.; Singh, H.; Hasan, M. Supercritical $\mathrm{CO}_{2}$ fractionation of crude palm oil. J. Supercrit. Fluids 2001, 20, 45-53.

78. Hassan, M.N.; Ab Rahman, N.N.; Anuar, B.O.; Ibrahim, M.H.; Mohd Omar, A.K. The effect of dehuling on supercritical extraction of palm kernel oil. J. Chem. Eng. Jpn. 2001, 34, 407-410.

79. Ragunnath, B.; Yamane, S.; Inomata, H.; Adschiri, T.; Arai, K. Phase equilibria of supercritical $\mathrm{CO}_{2}$ fatty oil component binary systems. Fluid Phase Equilib. 1993, 83, 183-192.

80. Lau, H.L.N.; Choo, Y.M.; Ma, A.N.; Chuah, C.H. Characterization and supercritical carbon dioxide extraction of palm oil (Elaeis guineensis). J. Food Lipids 2006, 13, 210-221.

81. Brunner, G. Fractionation of fats with supercritical carbon dioxide. Eur. J. Lipid Sci. Technol. 2000, 120, 240-244.

82. Cottrell, R.C. Introduction: Nutritional aspects of palm oil. Am. J. Clin. Nutr. 1991, 53, 989-1009. 
83. Baharin, B.S.; You, L.L.; Che Man, Y.B.; Takagi, S. Effect of degumming process on chromatographic separation of carotenes from crude and degummed palm oil. J. Food Lipids 2001, 8, 27-35.

84. de Franca, L.F.; Meireles, M.A.A. Modeling the extraction of carotene and lipids from pressed palm oil (Elaeis guineensis) fibers using supercritical $\mathrm{CO}_{2}$. J. Supercrit. Fluids 2000, 18, 35-47.

85. Davarnejad, R.; Kassim, K.M.; Zainal, A.; Sata, S.A. Supercritical fluid extraction of $\beta$-carotene from crude palm oil using $\mathrm{CO}_{2}$. J. Food Eng. 2008, 89, 472-478.

86. Favati, F.; King, J.W.; Friedrich, J.P.; Eksins, K. Supercritical CO2 extraction of carotene and lutein from leaf protein concentrates. J. Food Sci. 1988, 53, 1532-1536.

87. Goto, M.; Sato, M.; Hirose, T. Supercritical Carbon Dioxide Extraction of Carotenoids from Carrots. In Proceedings of the Sixth International Congress on Engineering and Food, Yano, T., Matsuno, R., Nakamura, K., Eds.; Blackie Academic \& professional: London, UK, 1994; p. 835.

88. Johannsen, M.; Brunner, G. Solubilities of the fat-soluble vitamins A, D, E and K in supercritical carbon dioxide. J. Chem. Eng. Data 1997, 42, 106-111.

89. Casas, L.; Mantell, C.; Rodríguez, M.; Torres, A.; Macías, F.A.; Martínez de la Ossa, E.J. Supercritical fluid extraction of bioactive compounds from sunflower leaves with carbon dioxide and water on a pilot plant scale. J. Supercrit. Fluids 2008, 45, 37-42.

90. Mezzomo, N.; Martínez, J.; Ferreira, S.R.S. Supercritical fluid extraction of peach (Prunus persica) almond oil: Kinetics, mathematical modeling and scale-up. J. Supercrit. Fluids 2009, $51,10-16$.

91. Reverchon, E.; Adami, R.; Caputo, G. Supercritical assisted atomization: Performance comparison between laboratory and pilot scale. J. Supercrit. Fluids 2006, 37, 298-306.

92. Sovová, H. Rate of the vegetable oil extraction with supercritical CO2-I. Modeling of extraction curves. Chem. Eng. Sci. 1994, 49, 409-414.

93. Sovová, H. Mathematical model for supercritical fluid extraction of natural products and extraction curve evaluation. J. Supercrit. Fluids 2005, 33, 35-52.

94. Oliveira, E.L.G.; Silvestre, A.J.D.; Silva, C.M. Review of kinetic models for supercritical fluid extraction. Chem. Eng. Res. Des. 2011, 89, 1104-1117.

95. Aro, H.; Järvenpää, E.P.; Könkö, K.; Sihvonen, M.; Hietaniemi, V.; Huopalahti, R. Isolation and purfication of egg yolk phospholipids using liquid extraction and pilot-scale supercritical liquid techniques. Eur. Food Res. Technol. 2009, 228, 857-863.

96. Pettinello, G.; Bertucco, A.; Pallado, P.; Stassi, A. Production of EPA enriched mixtures by supercritical fluid chromatography: from the laboratory scale to the pilot plant. J. Supercrit. Fluids 2000, 19, 51-60.

97. Oldshue, J.Y. Scale-Up. In Fluid Mixing Technology; McGraw-Hill Publications Co.: New York, NY, USA, 1983; pp. 192-215.

98. Corley, R.H.V. How much palm oil do we need? Environ. Sci. Policy 2009, 12, 134-139.

99. Berger, K.G.; Idris, N.A. Formulation of zero-trans acid shortenings and margarines and other food fats with products of oil palm. J. Am. Oil Chem. Soc. 2005, 82, 775-782.

100. Martínez, M.L.; Mattea, M.A.; Maestri, D.M. Pressing and supercritical carbon dioxide extraction of walnut oil. J. Food Eng. 2008, 88, 399-404. 
101. Glišić, S.B.; Mišić, D.R.; Stamenić, M.D.; Zizovic, I.T.; Ašanin, R.M.; Skala, D.U. Supercritical carbon dioxide extraction of carrot fruit essential oil: Chemical composition and antimicrobial activity. Food Chem. 2007, 105, 346-352.

102. Bravi, M.; Spinoglio, F.; Verdone, N.; Adami, M.; Aliboni, A.; D’Andrea, A.; de Santis, A.; Ferri, D. Improving the structure of $\alpha$-tocopherol-enriched oil from grape seeds by supercritical $\mathrm{CO}_{2}$. Optimisation of the extraction conditions. J. Food Eng. 2007, 78, 488-493.

103. Shi, J.; Yi, C.; Ye, X.; Xue, S.; Jiang, Y.; Ma, Y.; Liu, D. Effects of supercritical $\mathrm{CO}_{2}$ fluid parameters on chemical composition and yield of carotenoids extracted from pumpkin. Food Sci. Technol. 2010, 43, 39-44.

104. Sánchez-Vicente, Y.; Cabañas, A.; Renuncio, J.A.R.; Pando, C. Supercritical fluid extraction of peach (Prunus persica) seed oil using carbon dioxide and ethanol. J. Supercrit. Fluids 2009, 49, 167-173.

105. Eastwood, M. Principles of Human Nutrition; Chapman \& Hall: London, UK, 1997.

106. Özkal, S.G.; Yener, M.E.; Baymdirh, L. Mass transfer modeling of apricot kernel oil extraction with supercritical carbon dioxide. J. Supercrit. Fluids 2005, 35, 119-127.

107. Pederssetti, M.M.; Palú, F.; da Silva, E.A.; Rohling, J.H.; Cardozo-Filho, L.; Dariva, C. Extraction of canola seed (Brassica napus) oil using compressed propane and supercritical carbon dioxide. J. Food Eng. 2011, 102, 189-196.

108. Stahl, E.; Schutz, E.; Mangold, H.K. Extraction of seed oils with liquid and supercritical carbon dioxide. J. Agric. Food Chem. 1980, 28, 1153-1157.

109. Salgin, U. Extraction of jojoba seed oil using supercritical $\mathrm{CO}_{2}+$ ethanol mixture in green and high-tech separation process. J. Supercrit. Fluids 2007, 39, 330-337.

110. Corso, M.P.; Fagundes-Klena, M.R.; Silva, E.A.; Filhob, L.C.; Santos, J.N.; Freitas, L.S.; Dariva, C. Extraction of sesame seed (Sesamun indicum L.) oil using compressed propane and supercritical carbon dioxide. J. Supercrit. Fluids 2010, 52, 56-61.

111. Louli, L.; Folas, G.; Voutsas, E.; Magoulas, K. Extraction of parsley seed oil by supercritical $\mathrm{CO}_{2}$. J. Supercrit. Fluids 2004, 30, 163-174.

112. Westerman, D.; Santos, R.C.D.; Bosley, J.A.; Rogers, J.S.; Al-Duri, B. Extraction of Amaranth seed oil by supercritical carbon dioxide. J. Supercrit. Fluids 2006, 37, 38-52.

113. Gómez, A.M.; de la Ossa, E.M. Quality of borage seed oil extracted by liquid and supercritical carbon dioxide. Chem. Eng. J. 2002, 88, 103-109.

114. Pradhan, R.C.; Meda, V.; Rout, P.K.; NaiK, S.; Dalai, A.K. Supercritical CO2 extraction of fatty oil from flaxseed and comparison with screw press expression and solvent extraction processes. J. Food Eng. 2010, 98, 393-397.

115. Beveridge, T.H.J.; Girard, B.; Kopp, T.; Drover, J.C.G. Yield and composition of grape seed oils extracted by supercritical carbon dioxide and petroleum ether: Varietal effects. J. Agric. Food Chem. 2005, 53, 1799-1804.

116. Marrone, C.; Poletto, M.; Reverchon, E.; Stassi, A. Almond oil extraction by supercritical CO2: Experiment and modeling. Chem. Eng. Sci. 1998, 53, 3711-3718.

117. Goodrum, J.W.; Kilgo, M.B. Peanut oil extraction with SCCO2: Solubility and kinetic functions. Trans. ASAE 1987, 30, 1865-1868. 
118. Palazoglu, T.K.; Balaban, M.O. Supercritical CO2 extraction of lipids from roasted pistachio nuts. Trans. ASABE 1998, 41, 679-684.

119. Bernardo-Gil, M.G.; Lopes, I.M.G.; Casquilho, M.; Ribeiro, M.A.; Esquível, M.M.; Empis, J. Supercritical carbon dioxide extraction of acorn oil. J. Supercrit. Fluids 2007, 40, 344-348.

120. Sodeifian, G.; Ansari, K. Optimization of Ferulago Angulata oil extraction with supercritical carbon dioxide. J. Supercrit. Fluids 2011, 57, 38-43.

121. Follegatti-Romero, L.A.; Piantino, C.P.; Grimaldi, R.; Cabral, F.A. Supercritical $\mathrm{CO}_{2}$ extraction of omega-3 rich oil from Sacha inchi (Plukenetia volubilis L.) seeds. J. Supercrit. Fluids 2009, $49,323-329$.

122. Nik Norulaini, N.A.; Anuar, O.; Abbas, F.M.A.; Fatehah, M.O.; Mohd Omar, A.K.; Sahena, F.; Zaidul, I.S.M. Optimization of supercritical $\mathrm{CO}_{2}$ extraction of Anastatica Hierochuntica. Food Bioprod. Process. 2009, 87, 152-158.

123. Hamdana, S.; Daooda, H.G.; Toth-Markus, M.; Illés, V. Extraction of cardamom oil by supercritical carbon dioxide and sub-critical propane. J. Supercrit. Fluids 2008, 44, 25-30.

124. Bhattacharjee, P.; Singhal, R.S.; Tiwari, S.R. Supercritical carbon dioxide extraction of cottonseed oil. J. Food Eng. 2007, 79, 892-898.

125. Chan, K.W.; Ismail, M. Supercritical carbon dioxide fluid extraction of Hibiscus cannabinus L. seed oil: A potential solvent-free and high antioxidative edible oil. Food Chem. 2009, 114, 970-975.

126. Liu, S.; Yangb, F.; Zhanga, C.; Ji, H.; Honga, P.; Denga, C. Optimization of process parameters for supercritical carbon dioxide extraction of Passiflora seed oil by response surface methodology. J. Supercrit. Fluids 2009, 48, 9-14.

127. Abbasi, H.; Rezaei, K.; Rashidi, L. Extraction of essential oils from the seeds of pomegranate using organic solvents and supercritical $\mathrm{CO}_{2}$. J. Am. Oil Chem. Soc. 2008, 85, 83-89.

128. Mitra, P.; Ramaswamy, H.S.; Chang, K.S. Pumpkin (Cucurbita maxima) seed oil extraction using supercritical carbon dioxide and physicochemical properties of the oil. J. Food Eng. 2009, 95, 208-213.

129. Machmudah, S.; Kawahito, Y.; Sasaki, M.; Goto, M. Supercritical CO2 extraction of rosehip seed oil: Fatty acids composition and process optimization. J. Supercrit. Fluids 2007, 41, 421-428.

130. Xu, X.; Gao, Y.; Liu, G.; Wanga, Q.; Zhao, J. Optimization of supercritical carbon dioxide extraction of sea buckthorn (Hippophaë thamnoides L.) oil using response surface methodology. Food Sci. Technol. 2008, 41, 1223-1231.

131. Nik Norulaini, N.A.; Zaidul, I.S.M.; Azizi, C.Y.M.; Zhari, I.; Noramin, M.N.; Sahena, F.; Omar, A.K.M. Supercritical carbon dioxide fractionation of pithecellobium Jiringan jack seed compositions using fast gas chromatography time of flight mass spectrometry. J. Food Process Eng. 2011, 34, 1746-1758.

132. Rodrigues, V.M.; Rosa, P.T.; Marques, M.O.; Petenate, A.J.; Meireles, M.A. Supercritical extraction of essential oil from aniseed (Pimpinella anisum L.) using $\mathrm{CO}_{2}$ : Solubility, kinetics, and composition data. J. Agric. Food. Chem. 2003, 51, 1518-1523.

133. Illés, V.; Daood, H.G.; Perneczki, S.; Szokonya, L.; Then, M. Extraction of coriander seed oil by $\mathrm{CO}_{2}$ and propane at super- and subcritical conditions. J. Supercrit. Fluids 2000, 17, 177-186.

134. Bernardo-Gil, G.; Oneto, C.; Antunes, P.; Rodrigues, M.F.; Empis, J.M. Extraction of lipids from cherry seed oil using supercritical carbon dioxide. Eur. Food. Res. Technol. 2001, 212, 170-174. 
135. Favati, F.; King, J.W.; Mazzanti, M. Supercritical carbon dioxide extraction of evening primrose oil. J. Am. Oil. Chem. Soc. 1991, 68, 6.

136. Castro-Vargas, H.I.; Rodríguez-Varela, L.I.; Parada-Alfonso, F. Guava (Psidium guajava L.) seed oil obtained with a homemade supercritical fluid extraction system using supercritical $\mathrm{CO}_{2}$ and co-solvent. J. Supercrit. Fluids 2011, 56, 238-242.

137. Mira, B.; Blasco, M.; Berna, A.; Subirats, S. Supercritical $\mathrm{CO}_{2}$ extraction of essential oil from orange peel. Effect of operation conditions on the extract composition. J. Supercrit. Fluids 1999, 14, 95-104.

138. Nik Norulaini, N.A.; Setianto, W.B.; Zaidul, I.S.M.; Nawi, A.H.; Azizi, C.Y.M.; Omar, A.K.M. Effects of supercritical carbon dioxide extraction parameters on virgin coconut oil yield and medium-chain triglyceride content. Food Chem. 2009, 116, 193-197.

139. Özkal, S.G.; Salgin, U.; Yener, M.E. Supercritical carbon dioxide extraction of hazelnut oil. J. Food. Eng. 2005, 69, 217-223.

140. Shao, P.; Sun, P.; Ying, Y. Response surface optimization of wheat germ oil yield by supercritical carbon dioxide extraction. Food Bioprod. Process. 2008, 86, 227-231.

141. Shen, Z.; Palmer, M.V.; Ting, S.S.T.; Fairclough, R.J. Pilot scale extraction and fractionation of rice bran oil with dense carbon dioxide. J. Am. Oil Chem. Soc. 1996, 44, 3033-3039.

142. Andersson, M.B.O.; Demirbuker, M.; Blomberg, L.G. Semi-continuous extraction/purification of lipids by means of supercritical fluids. J. Chromatogr. A 1997, 785, 337-343.

143. Danh, L.T.; Truong, P.; Mammucari, R.; Foster, N. Extraction of vetiver essential oil by ethanol-modified supercritical carbon dioxide. Chem. Eng. J. 2010, 165, 26-34.

144. Wang, H.; Suoa, Y.; Wang, X.; Li, Y.; You, J.; Zhao, X. Extraction of Nitraria tangutorum seed oil by supercritical carbon dioxide and determination of free fatty acids by HPLC/APCI/MS with fluorescence detection. Sep. Purif. Technol. 2007, 56, 371-377.

145. Zhang, S.; Zu, Y.-G.; Fu, Y.-J.; Luo, M.; Liu, W.; Li, J.; Efferth, T. Supercritical carbon dioxide extraction of seed oil from yellow horn (Xanthoceras sorbifolia Bunge.) and its anti-oxidant activity. Bioresour. Technol. 2010, 101, 2537-2544.

146. Gomes, P.B.; Mata, V.G.; Rodrigues, A.E. Production of rose geranium oil using supercritical fluid extraction. J. Supercrit. Fluids 2007, 41, 50-60.

147. Wei, Z.-J.; Liao, A.-M.; Zhang, H.-X.; Liu, J.; Jiang, S.-T. Optimization of supercritical carbon dioxide extraction of silkworm pupal oil applying the response surface methodology. Bioresour. Technol. 2009, 100, 4214-4219.

148. Daukšas, E.; Venskutonis, P.R.; Sivik, B. Supercritical CO2 extraction of the main constituents of lovage (Levisticum officinale Koch.) essential oil in model systems and overground botanical parts of the plant. J. Supercrit. Fluids 1999, 15, 51-62.

149. Povh, N.P.; Marques, M.O.M.; Meireles, M.A.A. Supercritical $\mathrm{CO}_{2}$ extraction of essential oil and oleoresin from chamomile (Chamomilla recutita [L.] Rauschert). J. Supercrit. Fluids 2001, 21, 245-256.

150. Carlson, L.H.C.; Machado, R.A.F.; Spricigo, C.B.; Pereira, L.K.; Bolzan, A. Extraction of lemongrass essential oil with dense carbon dioxide. J. Supercrit. Fluids 2001, 21, 33-39. 
151. Ferreira, S.R.S.; Nikolov, Z.L.; Doraiswamy, L.K.; Meireles, M.A.A.; Petenate, A.J. Supercritical fluid extraction of black pepper (Piper nigrun L.) essential oil. J. Supercrit. Fluids 1999, 14, 235-245.

(C) 2012 by the authors; licensee MDPI, Basel, Switzerland. This article is an open access article distributed under the terms and conditions of the Creative Commons Attribution license (http://creativecommons.org/licenses/by/3.0/). 